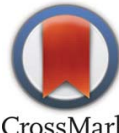

CrossMark

\section{OPEN ACCESS}

Citation: Thomas A, Hanel B, Marott JL, Buchvald F, Mortensen J, et al. (2014) The Single-Breath Diffusing Capacity of $\mathrm{CO}$ and NO in Healthy Children of European Descent. PLoS ONE 9(12): e113177. doi:10.1371/journal.pone.0113177

Editor: Paolo Montuschi, Catholic University of the Sacred Heart, Italy

Received: July 15, 2014

Accepted: October 8, 2014

Published: December 16, 2014

Copyright: (C) 2014 Thomas et al. This is an openaccess article distributed under the terms of the Creative Commons Attribution License, which permits unrestricted use, distribution, and reproduction in any medium, provided the original author and source are credited.

Data Availability: The authors confirm that all data underlying the findings are fully available without restriction. All relevant data are within the paper and its Supporting Information files.

Funding: Dagmar Marshalls Foundation URL: N/A, Carpenter Johannes Foghs Foundation http://www. fogfond.dk, Aase and Ejnar Danielsens Foundation http://www. danielsensfond.dk, The John and Birthe Meyer Foundation URL: N/A, Director Jacob Madsens Foundation URL: N/A. The funders had no role in study design, data collection and analysis, decision to publish, or preparation of the manuscript.

Competing Interests: The authors have declared that no competing interests exist.
RESEARCH ARTICLE

\section{The Single-Breath Diffusing Capacity of $\mathrm{CO}$ and NO in Healthy Children of European Descent}

\author{
Astrid Thomas ${ }^{1}$, Birgitte Hanel ${ }^{1}$, Jacob L. Marott ${ }^{2}$, Frederik Buchvald ${ }^{1}$, \\ Jann Mortensen ${ }^{3}$, Kim G. Nielsen ${ }^{1 *}$ \\ 1. Danish PCD \& chILD Centre, CF Centre Copenhagen, Pediatric Pulmonary Service, Department of \\ Pediatrics and Adolescent Medicine, Rigshospitalet, University of Copenhagen, Copenhagen, Denmark, 2. The \\ Copenhagen City Heart Study, Frederiksberg Hospital, Copenhagen, Denmark, 3. Department of Clinical \\ Physiology, Nuclear Medicine and PET, Rigshospitalet, University of Copenhagen, Copenhagen, Denmark \\ *kgn@dadlnet.dk
}

\section{Abstract}

Rationale: The diffusing capacity $\left(\mathrm{D}_{\mathrm{L}}\right)$ of the lung can be divided into two components: the diffusing capacity of the alveolar membrane (Dm) and the pulmonary capillary volume $(\mathrm{Vc})$. $\mathrm{D}_{\mathrm{L}}$ is traditionally measured using a single-breath method, involving inhalation of carbon monoxide, and a breath hold of 8-10 seconds $\left(D_{L, C O}\right)$. This method does not easily allow calculation of $\mathrm{Dm}$ and $\mathrm{Vc}$. An alternative single-breath method $\left(\mathrm{D}_{\mathrm{L}, \mathrm{CO}, \mathrm{NO}}\right)$, involving simultaneous inhalation of carbon monoxide and nitric oxide, and traditionally a shorter breath hold, allows calculation of $\mathrm{Dm}$ and $\mathrm{Vc}$ and the $\mathrm{D}_{\mathrm{L}, \mathrm{NO}} / \mathrm{D}_{\mathrm{L}, \mathrm{CO}}$ ratio in a single respiratory maneuver. The clinical utility of $\mathrm{Dm}, \mathrm{Vc}$, and $\mathrm{D}_{\mathrm{L}, \mathrm{NO}} / \mathrm{D}_{\mathrm{L}, \mathrm{CO}}$ in the pediatric age range is currently unknown but also restricted by lack of reference values.

Objectives: The aim of this study was to establish reference ranges for the outcomes of $D_{L, C O, N O}$ with a 5 second breath hold, including the calculated outcomes $\mathrm{Dm}, \mathrm{Vc}$, and the $\mathrm{D}_{\mathrm{L}, \mathrm{NO}} / \mathrm{D}_{\mathrm{L}, \mathrm{CO}}$ ratio, as well as to establish reference values for the outcomes of the traditional $D_{L, C O}$ method, with a 10 second breath hold in children.

Methods: $\mathrm{D}_{\mathrm{L}, \mathrm{CO}, \mathrm{NO}}$ and $\mathrm{D}_{\mathrm{L}, \mathrm{CO}}$ were measured in healthy children, of European descent, aged 5-17 years using a Jaeger Masterscreen PFT. The data were analyzed using the Generalized Additive Models for Location Scale and Shape (GAMLSS) statistical method.

Measurements and Main Results: A total of 326 children were eligible for diffusing capacity measurements, resulting in 312 measurements of $D_{L, C O, N O}$ and 297 of $D_{L, C O}$, respectively. Reference equations were established for the outcomes of $D_{L, C O, N O}$ and $D_{L, C O}$, including the calculated values: $V c, D m$, and the $D_{L, N O} / D_{L, C O}$ ratio. 
Conclusion: These reference values are based on the largest sample of children to date and may provide a basis for future studies of their clinical utility in differentiating between alterations in the pulmonary circulation and changes in the alveolar membrane in pediatric patients.

\section{Introduction}

The transfer factor of the lung for a gas, is often called the diffusing capacity of the lung $\left(D_{L}\right) . D_{L}$ for an inhaled gas reactive with hemoglobin is the flow of that gas from the alveoli to the blood for a unit difference in pressure. $D_{L}$ can be divided into two components: the diffusing capacity of the pulmonary membrane (Dm) and the chemical reaction of the gas binding to the blood. The latter is determined by the specific conductance of blood for a given gas, $\Theta$, and the capillary volume of the lung $(\mathrm{Vc})$.

The single-breath method was first introduced in 1915 [1]. Today, the singlebreath $\mathrm{D}_{\mathrm{L}}$ of carbon monoxide (CO) using a breath-hold of 10 seconds $\left(\mathrm{D}_{\mathrm{L}, \mathrm{CO}, 10 \mathrm{~s}}\right)$ is the most frequently used method with the current ATS/ERS methodological guidelines [2].

In 1957, Roughton and Forster proposed a method of calculating Dm and Vc, using $\mathrm{D}_{\mathrm{L}, \mathrm{CO}, 10 \mathrm{~s}}$, which required arterial samples and two respiratory maneuvers at two different oxygen tensions [3] . In 1987, Guénard, Varène and Vaida [4] proposed an alternative method $\left(\mathrm{D}_{\mathrm{L}, \mathrm{CO}, \mathrm{NO}}\right)$ of determining $\mathrm{Vc}$ and $\mathrm{Dm}$ involving simultaneous inhalation of $\mathrm{CO}$ and nitric oxide (NO). Both $\mathrm{CO}$ and $\mathrm{NO}$ transfer are diffusion limited, but NO has approximately twice the physical diffusivity of $\mathrm{CO}$, and the affinity to hemoglobin for $\mathrm{NO}\left(\Theta_{\mathrm{NO}}\right)$ is approximately 250 times greater [5]. The implications have been described in detail elsewhere, but in summary $\Theta_{\mathrm{NO}}$ was previously assumed infinitely great [4]. However, recent studies have challenged this assumption, leading to proposal of a finite value of $\Theta_{\text {NO }}$. The consequence of the use of a finite value for NO blood conductance is that $\mathrm{D}_{\mathrm{L}, \mathrm{NO}}$ appears equally dependent on $\mathrm{Dm}$ and $\mathrm{Vc}$ as $\mathrm{D}_{\mathrm{L}, \mathrm{CO}}$ is mainly dependent on Vc. [] ], []] .

The calculation of Dm and Vc involves the resistance of the red blood cell to gas transfer $\left(\Theta_{\text {gas }}\right)$, but no consensus currently exists about the true value of $\Theta_{\mathrm{CO}}$.

With the previous assumption of an infinite value of $\Theta_{\mathrm{NO}}$, calculation of the $\mathrm{D}_{\mathrm{L}, \mathrm{NO}} / \mathrm{D}_{\mathrm{L}, \mathrm{CO}}$ ratio was thought to provide useful information about the differentiation between primary alveolar membrane impairment (low $\mathrm{D}_{\mathrm{L}, \mathrm{NO}}$ / $\mathrm{D}_{\mathrm{L}, \mathrm{CO}}$ ratio) [8], [9], [10] or abnormalities of the pulmonary circulation (high $\mathrm{D}_{\mathrm{L}, \mathrm{NO}} / \mathrm{D}_{\mathrm{L}, \mathrm{CO}}$ ratio) [11], potentially providing additional insights into more specific factors affecting $D_{L}$ [12]. Now that a finite value of $\Theta_{\mathrm{NO}}$ has been determined, new interpretations of the ratio will be necessary.

Determination of $\mathrm{Vc}$ and $\mathrm{Dm}$ using $\mathrm{D}_{\mathrm{L}, \mathrm{CO}, \mathrm{NO}}$ requires a single respiratory maneuver and allows simultaneous determination of $\mathrm{D}_{\mathrm{L}, \mathrm{CO}}, \mathrm{D}_{\mathrm{L}, \mathrm{NO}}$, as well as 
calculation of $\mathrm{D}_{\mathrm{L}, \mathrm{NO}} / \mathrm{D}_{\mathrm{L}, \mathrm{CO}}, \mathrm{Dm}$, and $\mathrm{Vc}$. In addition, $\mathrm{D}_{\mathrm{L}, \mathrm{CO}, \mathrm{NO}}$ generally involves a shorter breath-hold due to the fast disappearance of NO [4]. The present study used a breath-hold of 5 seconds $\left(\mathrm{D}_{\mathrm{L}, \mathrm{CO}, \mathrm{NO}, 5 \mathrm{~s}}\right)$. Reference equations for these outcomes of $\mathrm{D}_{\mathrm{L}, \mathrm{CO}, \mathrm{NO}, 5 \mathrm{~s}}$ in children are scarce. A study involving 50 children over 8 years of age has been published [13], as well as a more recent study involving 85 healthy North African boys, aged 8-16 years [14] whereas two larger studies recently produced reference equations for the more frequently used outcomes of $\mathrm{D}_{\mathrm{L}, \mathrm{CO}, 10 \mathrm{~s}}[\underline{\underline{15}}],[\underline{16}]$.

Despite similarities in the performed respiratory maneuver $\mathrm{D}_{\mathrm{L}, \mathrm{CO}, \mathrm{NO}, 5 \mathrm{~s}}$ and $\mathrm{D}_{\mathrm{L}, \mathrm{CO}, 10 \mathrm{~s}}$ are two distinctly separate methods, with multiple methodological differences.

The primary goal of this study was to calculate reference equations for the outcomes of $\mathrm{D}_{\mathrm{L}, \mathrm{CO}, \mathrm{NO}, 5 \mathrm{~s}}$ including $\mathrm{Dm}, \mathrm{Vc}$, and the $\mathrm{D}_{\mathrm{L}, \mathrm{NO}} / \mathrm{D}_{\mathrm{L}, \mathrm{CO}}$ ratio, in healthy children. Since no consensus guidelines exist for $\mathrm{D}_{\mathrm{L}, \mathrm{CO}, \mathrm{NO}, 5 \mathrm{~s}}$ and previous data is limited, contemporary measurement of the frequently used $\mathrm{D}_{\mathrm{L}, \mathrm{CO}, 10 \mathrm{~s}}$ was performed to allow assessment of correlation between these two substantially different techniques and to assess whether they could be used interchangeably, although, knowing for a fact, that significant methodological differences exist. The resulting measurements of $\mathrm{D}_{\mathrm{L}, \mathrm{CO}, 10 \mathrm{~s}}$ allowed establishment of reference equations and comparison with existing published reference equations for $\mathrm{D}_{\mathrm{L}, \mathrm{CO}, 10 \mathrm{~s}}$. Some of the results of this study have been previously reported in the form of an abstract [17].

\section{Materials and Methods}

The regional ethics committee of Copenhagen ("De Videnskabsetiske Komiteer i Region Hovedstaden") approved the project, and all subjects and/or their parents provided written, informed consent (approval number: H-4-2011-111).

\section{Design and Subjects}

In this cross-sectional, single-center study, healthy children and adolescents aged between 5 and 17 years were recruited from December 2011 to August 2012 from a private combined elementary and high school in Copenhagen, a public elementary school in rural Denmark, and among the healthy siblings of patients, and the children of staff at the Danish Pediatric Pulmonary Service. Prior to participation, the children ( $>15$ years) or their parents were asked to fill out a health questionnaire covering gestational age, previous or current pulmonary disease, atopic illness, allergies, and any additional diseases the child had had, as well as current and previous medications.

All participants were non-smokers, had two parents of European descent, and had no current pulmonary or cardiac disease, including any upper or lower respiratory infection 2 weeks prior to the measurements. Any use of bronchodilators, and in particular, use in the day previous to participation, was 
considered an exclusion criterion. Furthermore, we excluded participants with $\mathrm{FEV}_{1} / \mathrm{FVC}$ below the age- and weight-specific lower limit according to recent data [18] or who were unable to co-operate or perform adequate respiratory maneuvers.

\section{Methods}

Height and weight were measured without shoes to the nearest $0.1 \mathrm{~cm}$ and 100 grams, respectively, using standard stadiometers (Seca, Hamburg, Germany) and scales. Age was calculated by difference between date of birth and participation date, and was recorded to decimal accuracy.

Hemoglobin concentration was measured by a finger stick blood sample test (The HemoCue Hb 201+; HemoCue, Denmark) in all participants unless the child refused. Correction for hemoglobin concentration is not imperative in healthy children, as variations within the normal range do not significantly affect $D_{L, C O}$ [19]. In children who refused hemoglobin measurement, we assumed normal values of $13.4 \mathrm{~g} / \mathrm{dL}(8.3 \mathrm{mmol} / \mathrm{L})$ for females, as well as males up to 15 years of age, and $14.6 \mathrm{~g} / \mathrm{dL}(9.0 \mathrm{mmol} / \mathrm{L})$ for males $>15$ years of age according to ATS/ ERS guidelines [2].

\section{Measurements of lung function}

Spirometry, $\mathrm{D}_{\mathrm{L}, \mathrm{CO}, \mathrm{NO}, 5 \mathrm{~s}}$, and $\mathrm{D}_{\mathrm{L}, \mathrm{CO}, 10 \mathrm{~s}}$ were performed using the Jaeger Masterscreen PFT pro (CareFusion, Hoechberg, Germany). Two identical sets of equipment were used at the three locations: one was used at the two participating schools and the other at the Danish Pediatric Pulmonary Service. Two experienced technicians performed all of the measurements. For most participants, spirometry and measurements of diffusing capacity were performed in a single sitting, but occasionally it required two sittings due to weariness with decreasing ability to perform technically acceptable measurements, especially with the younger children. If a participant was not able to make technically acceptable measurements in all three pulmonary function tests during the first sitting, they were invited back a second time. Spirometry always preceded the diffusing capacity measurements; $\mathrm{D}_{\mathrm{L}, \mathrm{CO}, \mathrm{NO}, 5 \mathrm{~s}}$ and $\mathrm{D}_{\mathrm{L}, \mathrm{CO}, 10 \mathrm{~s}}$ were performed in a random order except in the youngest children, in whom $\mathrm{D}_{\mathrm{L}, \mathrm{CO}, \mathrm{NO}, 5 \mathrm{~s}}$ was measured first because it was the primary goal of this study.

Participants breathed through a single-use mouthpiece with a built-in bacterial/viral filter (Spirobach, Tyco, Healthcare, Italy) connected to the pneumotachograph.

\section{Diffusing capacity measurements}

Participants were instructed to breathe normally. Following two to three normal breaths, participants performed a deep expiration and then a complete and fast inspiration. Following a breath-hold, a complete and smooth expiration was performed. As stated in the introduction $\mathrm{D}_{\mathrm{L}, \mathrm{CO}, \mathrm{NO}, 5 \mathrm{~s}}$ and $\mathrm{D}_{\mathrm{L}, \mathrm{CO}, 10 \mathrm{~s}}$ are performed 
with a identical respiratory maneuver, with the exception of breath-hold time, but it is important to clarify that they are two distinctly separate methods, contained within one equipment setup, with differences in test gasses, gas analyzers and sampling techniques.

See Table 1 for specific methodological differences between $\mathrm{D}_{\mathrm{L}, \mathrm{CO}, \mathrm{NO}, 5 \mathrm{~s}}$, and $\mathrm{D}_{\mathrm{L}, \mathrm{CO}, 10 \mathrm{~s}}$.

Quality control was performed separately for the two methods. Having unacceptable measurements for one method did not exclude the participant from attempting to perform the other method. The average of two acceptable tests for each method was reported and included in data analysis.

We required at least 4 minutes between each measurement, to allow adequate elimination of the test gases. Discard and sample volume were each $600 \mathrm{ml}$ in both $\mathrm{D}_{\mathrm{L}, \mathrm{CO}, \mathrm{NO}, 5 \mathrm{~s}}$ and $\mathrm{D}_{\mathrm{L}, \mathrm{CO}, 10 \mathrm{~s}}$. For children with a $\mathrm{VC}<1.5 \mathrm{~L}$ we reduced the discard volume to $500 \mathrm{ml}$ [2]. The gas concentration curves were viewed prior to sample collection to confirm that dead space washout was complete.

Breath-holding time was calculated using the Jones and Mead method for both $\mathrm{D}_{\mathrm{L}, \mathrm{CO}, \mathrm{NO}, 5 \mathrm{~s}}$ and $\mathrm{D}_{\mathrm{L}, \mathrm{CO}, 10 \mathrm{~s}}[\underline{20}]$.

The instrument dead space for both $\mathrm{D}_{\mathrm{L}, \mathrm{CO}, \mathrm{NO}, 5 \mathrm{~s}}$ and $\mathrm{D}_{\mathrm{L}, \mathrm{CO}, 10 \mathrm{~s}}\left(\mathrm{~V}_{\mathrm{D} \text {, ins }}\right)$ was $130 \mathrm{ml}$, and the anatomical dead space $\left(\mathrm{V}_{\mathrm{D} \text {,an }}\right)$ was calculated according to Cotes formula from 1993 as $\mathrm{V}_{\mathrm{D} \text {, an }}=2.2 \mathrm{ml} / \mathrm{kg} *$ weight in $\mathrm{kg}$ [21].

Alveolar volume $\left(\mathrm{V}_{\mathrm{A}}\right)$ was calculated using the following formula:

$$
\mathrm{V}_{\mathrm{A}}=\left(\mathrm{FI}_{\mathrm{gas}}\right) /\left(\mathrm{FA}_{\text {gas }}\right) *\left(\mathrm{~V}_{\mathrm{IN}}-\mathrm{V}_{\mathrm{D}, \text { an }}-\mathrm{V}_{\mathrm{D}, \text { ins }}\right)
$$

where $\mathrm{FI}_{\text {gas }}$ is the inspiratory fraction of inert gas (Methane or Helium for $\mathrm{D}_{\mathrm{L}, \mathrm{CO}, 10 \mathrm{~s}}$ and $\mathrm{D}_{\mathrm{L}, \mathrm{CO}, \mathrm{NO}, 5 \mathrm{~s}}$ respectively) and $\mathrm{FA}_{\mathrm{gas}}$ is the alveolar fraction of inert gas. $\mathrm{V}_{\mathrm{IN}}$ is the inspiratory volume.

All measurements were performed at sea level. $\mathrm{D}_{\mathrm{L}, \mathrm{CO}}$ and the diffusing capacity for $\mathrm{CO}$ per unit of alveolar volume $\left(\mathrm{D}_{\mathrm{L}, \mathrm{CO}} / \mathrm{V}_{\mathrm{A}}=\mathrm{K}_{\mathrm{CO}}\right)$ were corrected for

Table 1. Summary of methodology.

\begin{tabular}{|c|c|c|}
\hline & $\mathrm{D}_{\mathrm{L}, \mathrm{CO}, \mathrm{NO}, 5 \mathrm{~s}}$ & $\mathrm{D}_{\mathrm{L}, \mathrm{Co}, 10 \mathrm{~s}}$ \\
\hline Breath-hold & 5 seconds & 10 seconds \\
\hline Gas mixture & $\begin{array}{l}0.3 \% \mathrm{CO}, 9 \% \mathrm{He}, 20.9 \% \mathrm{O}_{2}, 69.8 \% \mathrm{~N}_{2} \text { mixed with } 400 \mathrm{ppm} \\
\mathrm{NO} / \mathrm{O}_{2}{ }^{*}\end{array}$ & $\begin{array}{l}0.3 \% \mathrm{CO}, 0.3 \% \mathrm{CH}_{4}, 20.9 \% \mathrm{O}_{2} \text {, and balanced } \\
\mathrm{N}_{2}\end{array}$ \\
\hline Inert gas & Helium & Methane \\
\hline Gas analyzer ${ }^{\dagger}$ & $\begin{array}{l}\text { NO: CiTicel 7BNT electrochemical cell, CO: Electrochemical Cell, } \\
\text { He: Thermal Conductivity, } \mathrm{O}_{2} \text { : Electrochemical Cell }\end{array}$ & $\mathrm{CO}, \mathrm{CH}_{4}$ : Non-dispersive infrared thermopile \\
\hline Gas sampling method & Physical sample from collection bag & $\begin{array}{l}\text { Virtual sample constructed from flow and gas } \\
\text { concentration signals. }\end{array}$ \\
\hline $\mathrm{CO}_{2}$-correction & $4,5 \%$ & - \\
\hline
\end{tabular}

$D_{\mathrm{L}, \mathrm{CO}, \mathrm{NO}, 5 \mathrm{~s}}$ represents the single-breath diffusing capacity for $\mathrm{NO}$ and $\mathrm{CO}$ with a 5-second breath-hold. $\mathbf{D}_{\mathrm{L}, \mathrm{CO}, 10 \mathrm{~s}}$ represents the single-breath diffusing capacity for $\mathrm{CO}$ with a 10-second breath-hold. Inert gas was used to measure the alveolar volume $\left(\mathrm{V}_{\mathrm{A}}\right)$.

*The concentration of NO in inspired gas was approximately 50 PPM according to the standard settings of the equipment.

${ }^{\dagger}$ City Tech. Ltd produced all gas analyzers.

${ }^{ \pm} \mathrm{CO}_{2}$ correction is applied due to cross-sensitivity of the Helium Analyser with $\mathrm{CO}_{2}$.

doi:10.1371/journal.pone.0113177.t001 
hemoglobin concentration when available. $\mathrm{D}_{\mathrm{L}, \mathrm{NO}}$ and the diffusing capacity for $\mathrm{NO}$ per unit of $\mathrm{V}_{\mathrm{A}}\left(\mathrm{D}_{\mathrm{L}, \mathrm{NO}} / \mathrm{V}_{\mathrm{A}}=\mathrm{K}_{\mathrm{NO}}\right)$ were not corrected for hemoglobin concentration [6].

$\mathrm{D}_{\mathrm{L}, \mathrm{CO}, \mathrm{NO} 5 \mathrm{~s}}$ and $\mathrm{D}_{\mathrm{L}, \mathrm{CO}, 10 \mathrm{~s}}$ were performed according to current ATS/ERS guidelines [2], though we considered a ratio between inspiratory volume and FVC ( $\left.\mathrm{V}_{\text {IN }} / \mathrm{FVC}\right)>80 \%$ as sufficient, in contrast to a ratio $>85 \%$. The vital capacity (VC) was not measured in our subjects, but FVC acquired during spirometry was assumed to be equivalent to the $\mathrm{VC}$, as $\mathrm{FVC}$ has been shown to not differ significantly from VC in healthy subjects [22], [23].

Both $\mathrm{D}_{\mathrm{L}, \mathrm{CO}, 10 \mathrm{~s}}$ and $\mathrm{D}_{\mathrm{L}, \mathrm{CO}, \mathrm{NO}, 5 \mathrm{~s}}$ result in the measurement of $\mathrm{D}_{\mathrm{L}, \mathrm{CO}}, \mathrm{V}_{\mathrm{A}}$, and $\mathrm{K}_{\mathrm{CO}}$. In addition, $\mathrm{D}_{\mathrm{L}, \mathrm{CO}, \mathrm{NO}, 5 \mathrm{~s}}$ produces measurements of $\mathrm{D}_{\mathrm{L}, \mathrm{NO}}, \mathrm{K}_{\mathrm{NO}}$, and allows calculation of $\mathrm{Dm}, \mathrm{Vc}$, and $\mathrm{D}_{\mathrm{L}, \mathrm{NO}} / \mathrm{D}_{\mathrm{L}, \mathrm{CO}(5 \mathrm{~s})}$. To differentiate between the two methods, $\mathrm{D}_{\mathrm{L}, \mathrm{CO}, 10 \mathrm{~s}}$ outcomes are denoted with "10s" and $\mathrm{D}_{\mathrm{L}, \mathrm{CO}, \mathrm{NO}, 5 \mathrm{~s}}$ outcomes

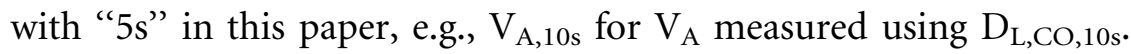

\section{Quality control of equipment}

Volume and gas calibration and biological quality control was performed daily prior to the measurements. Calibration syringes were tested for volume accuracy and were in accordance with ATS/ERS standards [2]. Gas-analyzers were factory checked and quality controlled for linearity as required for the $\mathrm{D}_{\mathrm{L}, \mathrm{CO}, 10 \mathrm{~s}}$ method before start of the study and after completion of the study in both sets of equipment, and were found in accordance with ATS/ERS standards. A quality control report on both sets of equipment is provided in Supporting Information. Appendix S1. Biological quality control of measurements using both $\mathrm{D}_{\mathrm{L}, \mathrm{CO}, 10 \mathrm{~s}}$ and $\mathrm{D}_{\mathrm{L}, \mathrm{CO}, \mathrm{NO}, 5 \mathrm{~s}}$ in addition to assessments of volumes demonstrated high levels of repeatability within subjects, between session and between equipment setups during the entire study period.

\section{Calculation of $\Theta$ and $\mathrm{Vc}_{\mathrm{c}}$}

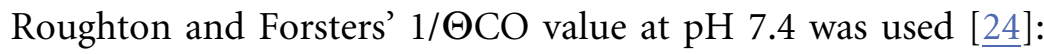

$$
1 / \Theta \mathrm{CO}=\left(1.30+0.0041 * \mathrm{PaO}_{2}\right) *(14.6 / \mathrm{Hb} \text { concentration in } \mathrm{g} / \mathrm{dL})
$$

$\mathrm{PaO}_{2}$ was set at $100 \mathrm{mmHg}$. Using the standard hemoglobin concentrations, 1/ $\Theta \mathrm{CO}$ was found to be 1.71 for females and for males $<15$ years of age, and 1.86 for males $>15$ years of age.

A $\mathrm{Dm}_{\mathrm{NO}} / \mathrm{Dm}_{\mathrm{CO}}$ ratio $(\alpha)$ of 1.97 [4] was used, and $\mathrm{Vc}$ was determined by isolating $1 / \mathrm{Vc}$ in the following equation:

$$
1 / \mathrm{D}_{\mathrm{L}, \mathrm{CO}}=1 / \mathrm{Dm}_{\mathrm{CO}}+1 / \Theta \mathrm{CO} * \mathrm{Vc}
$$

The calculations above assume the previously acknowledged infinite value of $\Theta_{\mathrm{NO}}$. Recently a finite value of $\Theta_{\mathrm{NO}}$ has been accepted as more accurate, and was therefore used in this study. The finite value of $\Theta_{\mathrm{NO}}$ leads to the following equations: 


$$
\mathrm{Vc}_{\text {finite }}=0.744 * \mathrm{Vc}_{\text {infinite }}
$$

and

$$
\mathrm{Dm}_{\text {finite }}=0.377 /\left(1 / \mathrm{D}_{\mathrm{L}, \mathrm{NO}}-0.13 / \mathrm{D}_{\mathrm{L}, \mathrm{CO}}\right)
$$

\section{Statistical analysis}

The primary outcomes for $\mathrm{D}_{\mathrm{L}, \mathrm{CO}, \mathrm{NO}, 5 \mathrm{~s}}$ were considered to be $\mathrm{D}_{\mathrm{L}, \mathrm{CO}, 5 \mathrm{~s}}, \mathrm{~K}_{\mathrm{CO}, 5 \mathrm{~s}}$, $\mathrm{V}_{\mathrm{A}, 5 \mathrm{~s}}, \mathrm{D}_{\mathrm{L}, \mathrm{NO}}, \mathrm{K}_{\mathrm{NO}}$, and the calculated outcomes $\mathrm{D}_{\mathrm{L}, \mathrm{NO}} / \mathrm{D}_{\mathrm{L}, \mathrm{CO}, 5 \mathrm{~s}}$, and $\mathrm{Vc}, \mathrm{Dm}$ for the finite value of $\Theta_{\mathrm{NO}}$. Primary outcomes for $\mathrm{D}_{\mathrm{L}, \mathrm{CO}, 10 \mathrm{~s}}$ were $\mathrm{D}_{\mathrm{L}, \mathrm{CO}, 10 \mathrm{~s}}, \mathrm{~K}_{\mathrm{CO}, 10 \mathrm{~s}}$, and $\mathrm{V}_{\mathrm{A}, 10 \mathrm{~s}}$. Reference equations were established using Generalized Additive Models for Location Scale and Shape (GAMLSS) with extended capabilities compared to the simpler, generalized linear models. The GAMLSS regression analysis allows the median or mean value $(m u)$, the variability (sigma), and the skewness $(n u)$ of the outcome variable to change with the explanatory variables. Possible distributions for the GAMLSS models were normal distribution (linear regression with $m u$ and sigma), gamma distribution ( $m u$ and sigma), or the BoxCox Cole and Green (BCCG) distribution ( $m u$, sigma, and $n u)$. The latter is suitable for skewed data.

Stepwise model selection was carried out using the Generalized Akaike Information Criterion (GAIC). Possible explanatory variables in the selection of $m u$, sigma, and $n u$ were age, sex, height, and cube of height, as well as any two-way interaction between these variables for mu. Goodness of fit was assessed by 'worm plots' and Q statistics [26], [27]. For all three distributions we investigated models with log mu links, log sigma links and for the Box-Cox Cole Green distribution identity nu links. Measurements not meeting ATS quality criteria $(>10 \%$ difference between to measurements, and $\mathrm{V}_{\text {IN }} / \mathrm{FVC}$ between $80 \%$ and $85 \%$ ) were included after evaluating the influence and leverage of the resulting data points in ordinary linear regression analysis [28], [29], [30], [31]. All analyses were performed using the statistical software $\mathrm{R}$ (version 3.0.2; R Foundation, http:// www.r-project.org) including the GAMLSS package.

\section{Results}

See figure 1 for the inclusion flow chart. Baseline characteristics are provided in table 2. The populations in our three locations were similar in all regards. See

Figure $\mathbf{S 1}$ for the age distribution.

Conformity between the two sets of equipment for $\mathrm{D}_{\mathrm{L}, \mathrm{CO}, 10 \mathrm{~s}}$ was evaluated using a paired t-test $(\mathrm{p}=0.62)$ and a Bland-Altman plot (mean difference $=0.06)$. See figure 2. 


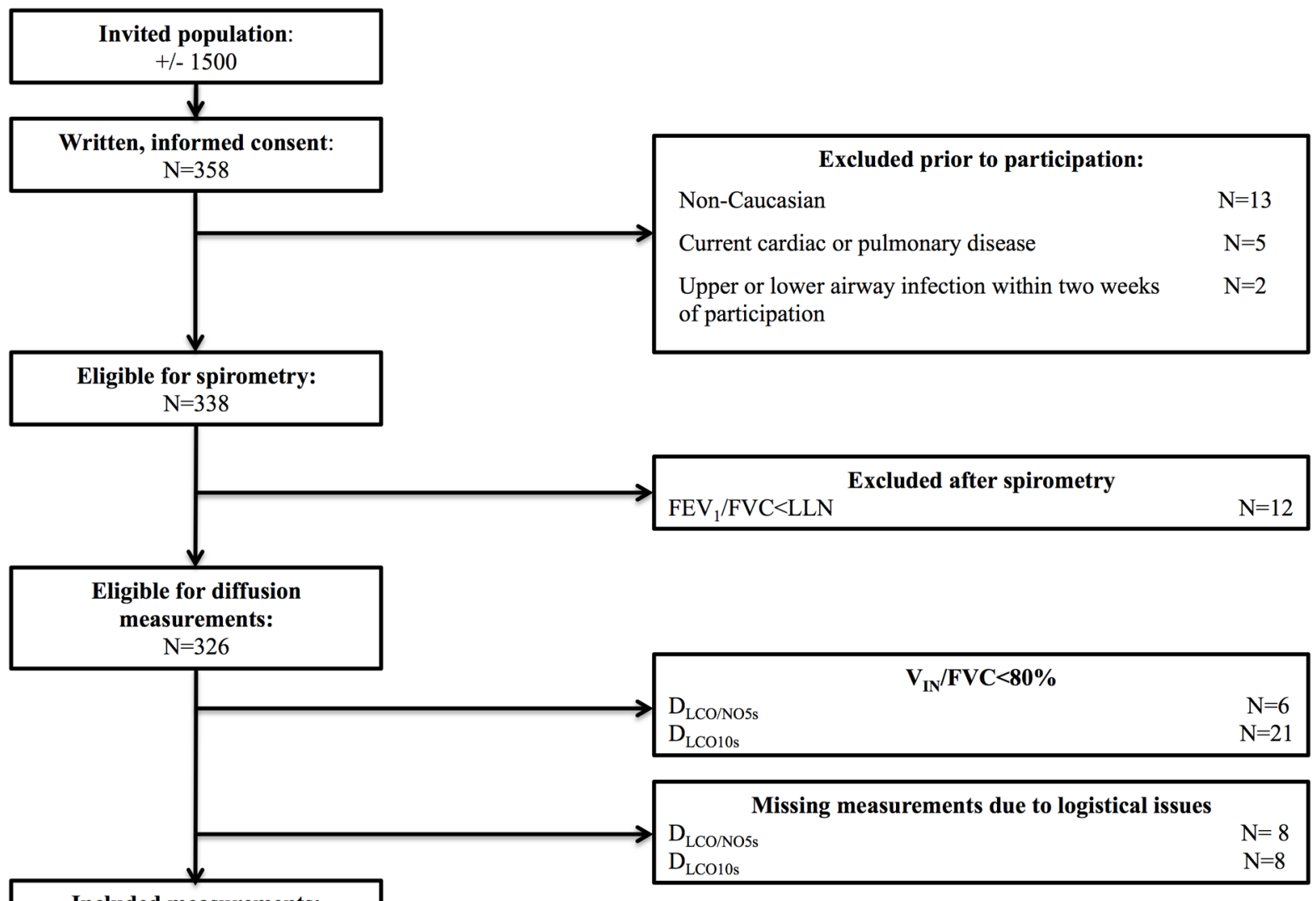

\begin{tabular}{|lr|}
\hline \multicolumn{2}{|c|}{ Included measurements: } \\
$\mathrm{D}_{\mathrm{LCO} / \mathrm{NO} 5 \mathrm{~s}}$ & $\mathrm{~N}=\mathbf{3 1 2}$ \\
$\mathrm{D}_{\mathrm{LCO} 10 \mathrm{~s}}$ & $\mathrm{~N}=\mathbf{2 9 7}$ \\
\hline
\end{tabular}

Figure 1. Inclusion flowchart. Invitations to participate were sent to approximately 1500 children, of which 358 participants and/or their parents provided informed consent.

doi:10.1371/journal.pone.0113177.g001

Table 2. Baseline characteristics at the three locations.

\begin{tabular}{ll|l|l|l} 
& & Private school, Copenhagen & $\begin{array}{l}\text { Pediatric Pulmonary Service, } \\
\text { Copenhagen }\end{array}$ & $\begin{array}{l}\text { Public school, rural } \\
\text { Denmark }\end{array}$ \\
N & & 159 & 55 & 112 \\
Sex (male) & $\mathrm{N}(\%)$ & $82(51.6)$ & $24(43.6)$ & $55(49.1)$ \\
Age (y) & Mean (SD) [range] & $11.4(3.3)[5-17]$ & $11.5(4.4)[5-17]$ & $10.3(2.9)[5-16]$ \\
Height (cm) & Mean (SD) [range] & $152.7(19.3)[104.9-187.6]$ & $150.5(24.2)[107.4-186.8]$ & $145.5(16.8)[108.0-182.0]$ \\
Weight (kg) & Mean (SD) [range] & $45.2(16.3)[18.8-93.6]$ & $45.9(19.2)[14.8-81.5]$ & $40.1(14.8)[18.1-101.2]$ \\
FEV ${ }_{1}$ (Z-score) & Mean (SD) [range] & $1.17(0.93)[-1.05-3.62]$ & $0.73(0.83)[-1.29-2.82]$ & $1.14(0.93)[-1.20-3.38]$ \\
FVC (Z-score) & Mean (SD) [range] & $1.16(0.95)[-0.89-3.97]$ & $0.62(0.81)[-1.01-2.50]$ & $1.11(1.04)[-1.31-4.10]$ \\
\hline
\end{tabular}

$\mathrm{FEV}_{1}=$ forced expiratory volume in one second, $\mathrm{FVC}=$ forced vital capacity, $\mathrm{SD}=$ standard deviation.

doi:10.1371/journal.pone.0113177.t002 


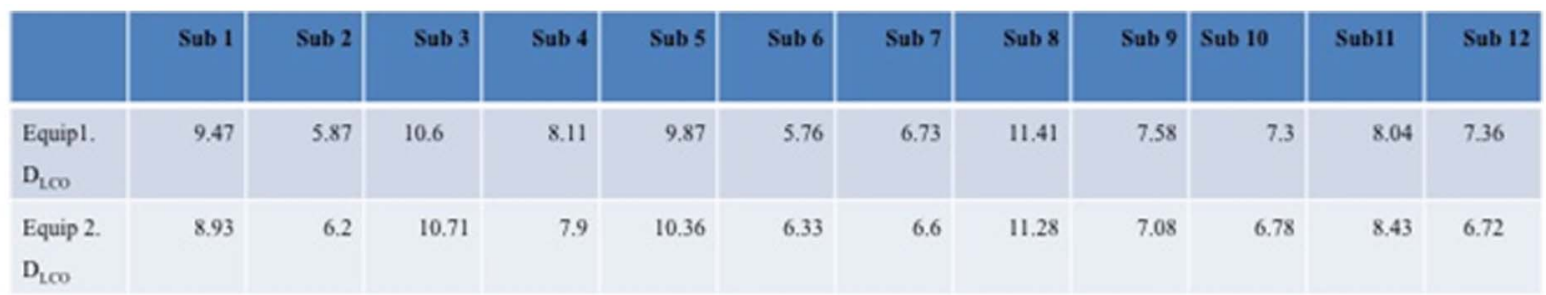

Result paired t-test: 0.62

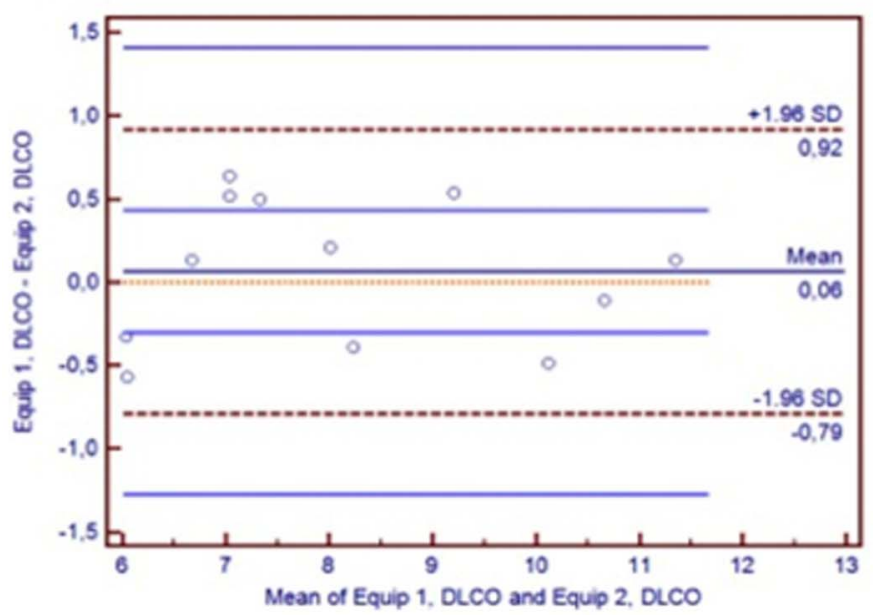

\author{
Bland-Altman plot: \\ Mean difference 0.06
}

Figure 2. Comparison using Bland and Altman plots of results in 12 subjects assessed by the two sets of equipment used. One at the Pediatric Pulmonary Service, Copenhagen and the other at the two schools involved.

doi:10.1371/journal.pone.0113177.g002

\title{
Reference equations
}

Reference equations, as well as the sigma for all outcomes, are presented in table 3 . In addition please see the provided excel spreadsheet, that allows calculation of predicted reference values.

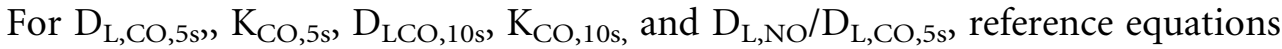
were produced for both hemoglobin-corrected and non-corrected values. Vc and Dm were calculated based on the finite value of $\Theta_{\mathrm{NO}}$.

Example of calculation:

The reference equation for $\mathrm{D}_{\mathrm{L}, \mathrm{CO}, 5 \mathrm{~s}}$ is:

$$
\mathrm{D}_{\mathrm{L}, \mathrm{CO}, 5 \mathrm{~s}}=\exp \left(0.9440+0.0205^{*} \mathrm{~A}+0.0908^{*} \mathrm{~S}+1.6233^{*} 10^{\wedge}-7^{*} \mathrm{H}^{\wedge} 3\right)
$$

A 10-year-old boy, $140 \mathrm{~cm}$ tall has a predicted $\mathrm{D}_{\mathrm{L}, \mathrm{CO}, 5 \mathrm{~s}}$ of:

$$
\begin{aligned}
\mathrm{D}_{\mathrm{L}, \mathrm{CO}, 5 \mathrm{~s}} & =\exp \left(0.9440+0.0205^{*} 10+0.0908^{*} 1+1.6233^{*} 10^{\wedge}-7^{*} 140^{\wedge} 3\right) \\
& =5.4(\mathrm{mmol} / \mathrm{min}) / \mathrm{kPa} .
\end{aligned}
$$


Table 3. Reference equations for $D_{L, C O, N O, 5 s}$ and $D_{L, C O, 10 s}$.

\begin{tabular}{|c|c|c|c|}
\hline $\mathrm{D}_{\mathrm{L}, \mathrm{CO}, \mathrm{NO}, 5 \mathrm{~s}}$ & Model & Equation (=mu) & $\begin{array}{l}\text { Coefficient of } \\
\text { variation } \\
\text { (=Sigma) }\end{array}$ \\
\hline $\mathrm{D}_{\mathrm{L}, \mathrm{NO}},(\mathrm{mmol} / \mathrm{min}) / \mathrm{kPa}^{*}$ & Gamma & $\begin{array}{l}\exp \left(1.3145+0.0214^{*} A-0.0058^{*} S+0.0119^{*} H-1.2893^{*} 10^{\wedge}\right. \\
\left.-8{ }^{*} H^{\wedge} 3+2.7070^{*} 10^{\wedge}-8^{*} S^{*} H^{\wedge} 3\right)\end{array}$ & $\exp (-2.2490)$ \\
\hline $\mathrm{K}_{\mathrm{NO}},((\mathrm{mmol} / \mathrm{min}) / \mathrm{kPa}) / \mathrm{L}^{\ddagger}$ & Normal & $\begin{array}{l}\exp \left(1.2672+1.1168^{*} \mathrm{~S}+0.0098^{*} \mathrm{H}-1.8280^{*} 10^{\wedge}-7^{*} \mathrm{H}^{\wedge}\right. \\
\left.3-0.0117^{*} \mathrm{~S}^{*} \mathrm{H}+1.9769^{*} 10^{\wedge}-7^{*} \mathrm{~S}^{*} \mathrm{H}^{\wedge} 3\right)\end{array}$ & $\exp (-0.3370)$ \\
\hline $\mathrm{D}_{\mathrm{L}, \mathrm{CO}, 5 \mathrm{~s}},(\mathrm{mmol} / \mathrm{min}) / \mathrm{kPa}^{\S}$ & Gamma & $\exp \left(0.9440+0.0205^{*} \mathrm{~A}+0.0908^{*} \mathrm{~S}+1.6233^{*} 10^{\wedge}-7^{*} \mathrm{H}^{\wedge} 3\right)$ & $\exp (-2.2521)$ \\
\hline $\mathrm{D}_{\mathrm{L}, \mathrm{CO}, 5 \mathrm{~s}, \mathrm{hb}-\text { corr }}(\mathrm{mmol} / \mathrm{min}) / \mathrm{kPa}$ & BCCG & $\exp \left(0.6392-0.0570^{*} \mathrm{~A}+0.0922^{*} \mathrm{~S}+0.0062^{*} \mathrm{H}+0.0005^{*} \mathrm{~A}^{*} \mathrm{H}\right)$ & $\exp (-2.2678)$ \\
\hline $\mathrm{K}_{\mathrm{CO}, 5 \mathrm{~s}},((\mathrm{mmol} / \mathrm{min}) / \mathrm{kPa}) / \mathrm{L} \|$ & Gamma & $\exp \left(0.9567+0.0576^{*} S-0.0028^{*} \mathrm{H}\right)$ & $\exp (-2.3644)$ \\
\hline $\mathrm{K}_{\mathrm{CO}, 5 \mathrm{~s}, \mathrm{hb}-\mathrm{corr},}((\mathrm{mmol} / \mathrm{min}) / \mathrm{kPa}) / \mathrm{L}$ & Gamma & $\exp \left(1.6187+0.0526^{*} S-0.0092^{*} \mathrm{H}+8.8280^{*} 10^{\wedge}-8^{*} \mathrm{H}^{\wedge} 3\right)$ & $\exp (-2.3626)$ \\
\hline $\mathrm{V}_{\mathrm{A}, 5 \mathrm{~s}}, \mathrm{~L}^{\dagger}$ & Gamma & $\exp \left(-0.6939-0.0181^{*} \mathrm{~A}+0.0409^{*} \mathrm{~S}+0.0111^{*} \mathrm{H}+0.0003^{*} \mathrm{~A}^{*} \mathrm{H}\right)$ & $\exp (-2.5047)$ \\
\hline $\mathrm{Vc}, \mathrm{ml}^{* *}$ & Gamma & $\exp \left(2.7298-0.0729^{*} A-0.0268^{*} S+0.0066^{*} H+0.0126^{*} A^{*} S+0.0005^{*} A^{*} H\right)$ & $\exp (-2.1027)$ \\
\hline $\mathrm{Dm},(\mathrm{ml} / \mathrm{min}) / \mathrm{mmHg}^{\dagger \dagger}$ & Gamma & $\exp \left(2.0825+0.0329^{\star} \mathrm{A}+0.0573^{*} \mathrm{~S}+0.0123^{*} \mathrm{H}\right)$ & $\exp (-1.9359)$ \\
\hline $\mathrm{D}_{\mathrm{L}, \mathrm{NO}} / \mathrm{D}_{\mathrm{L}, \mathrm{CO}, 5 \mathrm{~s}}$ & Normal & $\exp \left(0.9407+0.0458^{*} \mathrm{~A}+0.0039^{*} \mathrm{H}-0.0003^{*} \mathrm{~A}^{*} \mathrm{H}\right)$ & $\exp (-1.3398)$ \\
\hline$D_{L, C o, 10 s}$ & Model & Equation(=mu) & $\begin{array}{l}\text { Coefficient of } \\
\text { variation } \\
\text { (=Sigma) }\end{array}$ \\
\hline $\mathrm{D}_{\mathrm{L}, \mathrm{CO}, 10 \mathrm{~s},}(\mathrm{mmol} / \mathrm{min}) / \mathrm{kPa}$ & Gamma & $\exp \left(1.0826+0.0178^{*} \mathrm{~A}+0.0948^{*} \mathrm{~S}+1.5419^{*} 10^{\wedge}-7^{*} \mathrm{H}^{\wedge} 3\right)$ & $\exp (-2.1883)$ \\
\hline $\mathrm{D}_{\mathrm{L}, \mathrm{CO}, 10 \mathrm{~s}, \mathrm{hb}-\mathrm{corr}}(\mathrm{mmol} / \mathrm{min}) / \mathrm{kPa}$ & Gamma & $\exp \left(0.6371-0.0435^{*} \mathrm{~A}+0.0939^{*} \mathrm{~S}+0.0070^{*} \mathrm{H}+0.0004^{*} \mathrm{~A}^{*} \mathrm{H}\right)$ & $\exp (-2.2356)$ \\
\hline $\mathrm{V}_{\mathrm{A}, 10 \mathrm{~s}}, \mathrm{~L}$ & Gamma & $\begin{array}{l}\exp \left(-1.2915-0.1265^{*} A+0.0509^{*} S+0.0213^{*} H-2.4645^{*} 10^{\wedge}-7\right. \\
\left.{ }^{*} H^{\wedge} 3+0.0009^{*} A^{*} H\right)\end{array}$ & $\exp (-2.4837)$ \\
\hline $\mathrm{K}_{\mathrm{CO}, 10 \mathrm{~s}},((\mathrm{mmol} / \mathrm{min}) / \mathrm{kPa}) / \mathrm{L}$ & Gamma & $\exp \left(1.2115+0.0576^{*} S-0.0043^{*} H\right)$ & $\exp (-2.2442)$ \\
\hline $\mathrm{K}_{\mathrm{co}, 10 \mathrm{~s}, \mathrm{hb}-\mathrm{corr}},((\mathrm{mmol} / \mathrm{min}) / \mathrm{kPa}) / \mathrm{L}$ & Gamma & $\exp \left(1.2825+0.0566^{*} S-0.0047^{*} H\right)$ & $\exp (-2.2597)$ \\
\hline
\end{tabular}

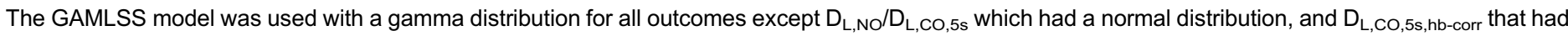
a Box-Cox-Cole-Green distribution (BCCG). $\mathrm{H}=$ height in $\mathrm{cm}, \mathrm{A}=$ age in years, $\mathrm{S}=$ sex $($ male=1, female=0),

${ }^{*} \mathrm{D}_{\mathrm{LNO}}=$ diffusing capacity for $\mathrm{NO}$,

$\mathrm{V}_{\mathrm{A}}=$ alveolar volume

${ }^{+} \mathrm{K}_{\mathrm{NO}}=\mathrm{D}_{\mathrm{LNO}} / \mathrm{N}_{\mathrm{A}}$,

${ }^{\S} \mathrm{D}_{\mathrm{LCO}}=$ diffusing capacity for $\mathrm{CO}, \| \mathrm{K}_{\mathrm{CO}}=\mathrm{D}_{\mathrm{L}, \mathrm{CO}} / \mathrm{V}_{\mathrm{A}}$,

${ }^{* *} \mathrm{Vc}=$ capillary volume

$\dagger^{\dagger} \mathrm{Dm}=$ diffusing capacity of the alveolar membrane.

The notation ${ }_{(10 \mathrm{~s})}$ and ${ }_{(5 \mathrm{~s})}$ indicates if the outcomes were found using the $\mathrm{D}_{\mathrm{L}, \mathrm{CO}, 10 \mathrm{~s}}$ method or the $\mathrm{D}_{\mathrm{L}, \mathrm{CO}, \mathrm{NO}, 5 \mathrm{~s}}$ method. "hb-corr" =values corrected for hemoglobin concentration.

doi:10.1371/journal.pone.0113177.t003

" $\mathrm{A}$ " is the age in years, " $\mathrm{S}$ " is the sex ( 1 for males and 0 for females), and " $\mathrm{H}$ " is the height in $\mathrm{cm}$.

When creating a "best-fit" model for the $\mathrm{D}_{\mathrm{L}, \mathrm{NO}} / \mathrm{D}_{\mathrm{L}, \mathrm{CO}, 5 \mathrm{~s}}$ ratio as a function of height, we saw that the ratio increased with height for the youngest participants and reached a plateau around age 14 (figure 3 ).

Our reference values for $\mathrm{D}_{\mathrm{L}, \mathrm{CO}, 10 \mathrm{~s}}$ and $\mathrm{K}_{\mathrm{CO}, 10 \mathrm{~s}}$ were comparable to published reference values (figure 4a-b) [16], [19].

We have provided an Excel calculation sheet based on both GAMLSS regression and linear regression, and an example of calculation. The excel sheet is provided as Appendix S2. 


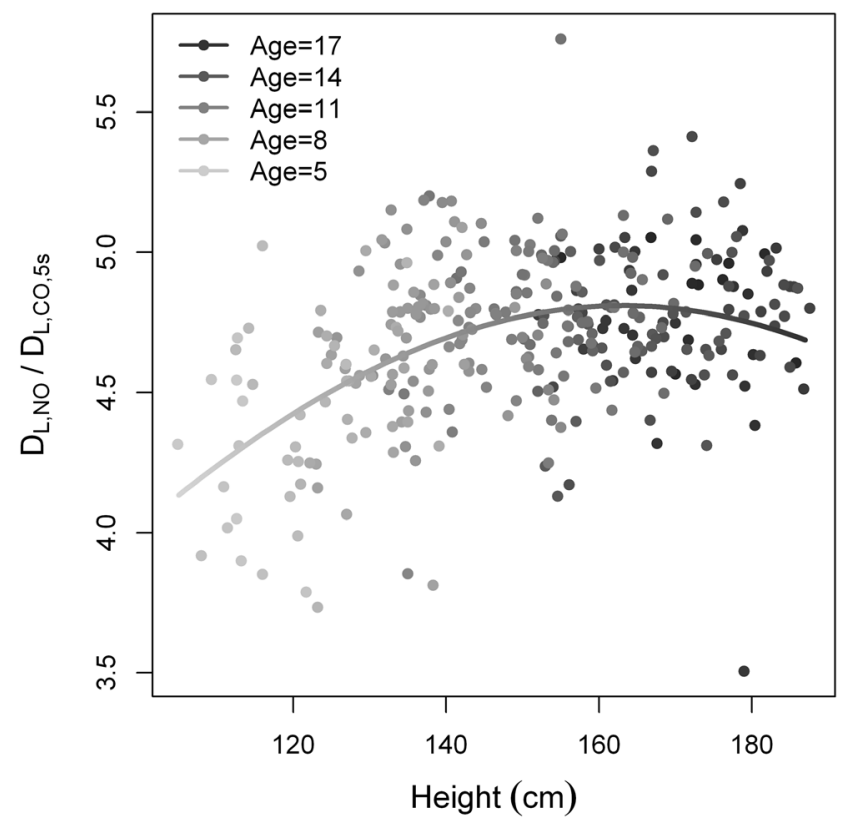

Figure 3. Scatter plot and curve of $D_{L, N O} / D_{L, C O, 5 s}$ versus height. Dot colors indicate participant age (light gray indicates the youngest and black dots the oldest).

doi:10.1371/journal.pone.0113177.g003

\section{Quality Control}

Repeatability of measurements in $\mathbf{5}$ to 8-year-olds and the $\mathrm{V}_{\mathbf{I N}} / \mathrm{FVC}$ ratio Young children were less likely to meet the guideline requiring less than $10 \%$ variation between two measurements of $\mathrm{D}_{\mathrm{LCO}, 5 \mathrm{~s}}$, inspiratory volume $\left(\mathrm{V}_{\mathrm{IN}, 5 \mathrm{~s}}\right)$, $\mathrm{D}_{\mathrm{L}, \mathrm{CO}, 10 \mathrm{~s}}$, and $\mathrm{V}_{\mathrm{IN}, 10 \mathrm{~s}}$. Including the mean of two measurements, not complying with ATS/ERS guidelines did not alter the reference equations (Figure S2, Figure S3, Figure S4 and Figure S5.).

Using the same procedure as described for the repeatability of measurements, we found little evidence that observations of $\mathrm{V}_{\text {IN }} / \mathrm{FVC}$ between $80 \%$ and $85 \%$ should be excluded (Figure S6 and Figure S7).

A

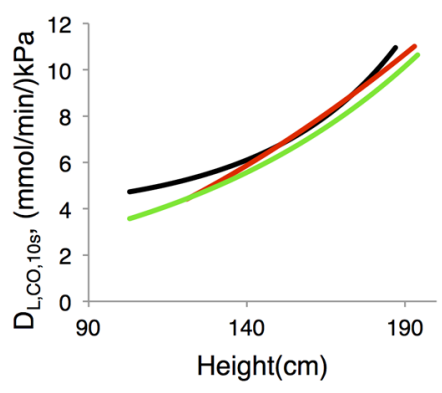

B

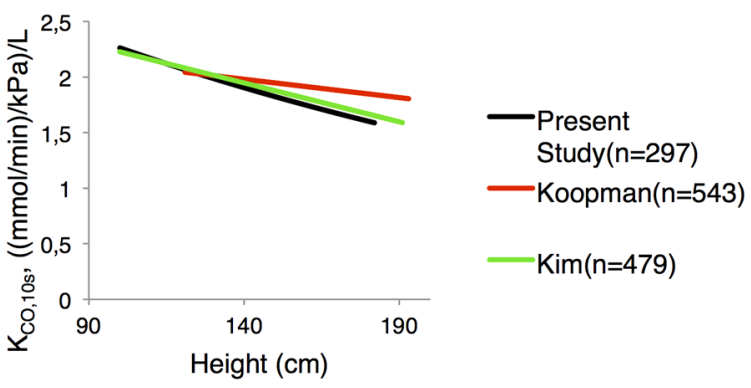

Figure 4. (a) $D_{L, C O, 10 s}$ and (b) $K_{C O(10 s)}$ compared to recent reference equations [16], [15]. The reference equations are plotted as a function of height. All other variables were kept constant.

doi:10.1371/journal.pone.0113177.g004 
The influence of a given data point, such as an outlier, cannot be evaluated using residuals or Z-scores, as highly influential points will force the regression line close to it, resulting in a small residual and Z-score. We found little evidence that participants who deviated from ATS/ERS guidelines should be excluded from the estimation of reference equations for $\mathrm{D}_{\mathrm{L}, \mathrm{CO}, 5 \mathrm{~s}}$ and $\mathrm{D}_{\mathrm{L}, \mathrm{CO}, 10 \mathrm{~s}}$, as the resulting data points were not highly influential, and excluding them did not alter the Z-scores. Therefore, including them in the data analysis was acceptable.

$D_{L, C O, 5 s}$ Vs. $D_{L, C O, 10 s}$

$\mathrm{D}_{\mathrm{L}, \mathrm{CO}, 10 \mathrm{~s}}$ was significantly higher than $\mathrm{D}_{\mathrm{L}, \mathrm{CO}, 5 \mathrm{~s}}$ (paired t-test $\mathrm{p}<0.0001$ ) but as expected, $\mathrm{D}_{\mathrm{L}, \mathrm{CO}, 10 \mathrm{~s}}$ and $\mathrm{D}_{\mathrm{L}, \mathrm{CO}, 5 \mathrm{~s}}$ were strongly correlated $(\mathrm{r}=0.98, \mathrm{p}<0.0001)$. Similarly, using the Passing Bablok regression, we found a systematic difference, as well as a proportional difference (figure 5).

When plotting $\mathrm{D}_{\mathrm{L}, \mathrm{CO}, 10 \mathrm{~s}}$ and $\mathrm{D}_{\mathrm{L}, \mathrm{CO}, 5 \mathrm{~s}}$ as a function of height, we found $\mathrm{D}_{\mathrm{L}, \mathrm{CO}, 10 \mathrm{~s}}>\mathrm{D}_{\mathrm{L}, \mathrm{CO}, 5 \mathrm{~s}}$. (Figure 6) as well as $\mathrm{V}_{\mathrm{A}, 10 \mathrm{~s}}>\mathrm{V}_{\mathrm{A}, 5 \mathrm{~s}}$ ( Figure 7).

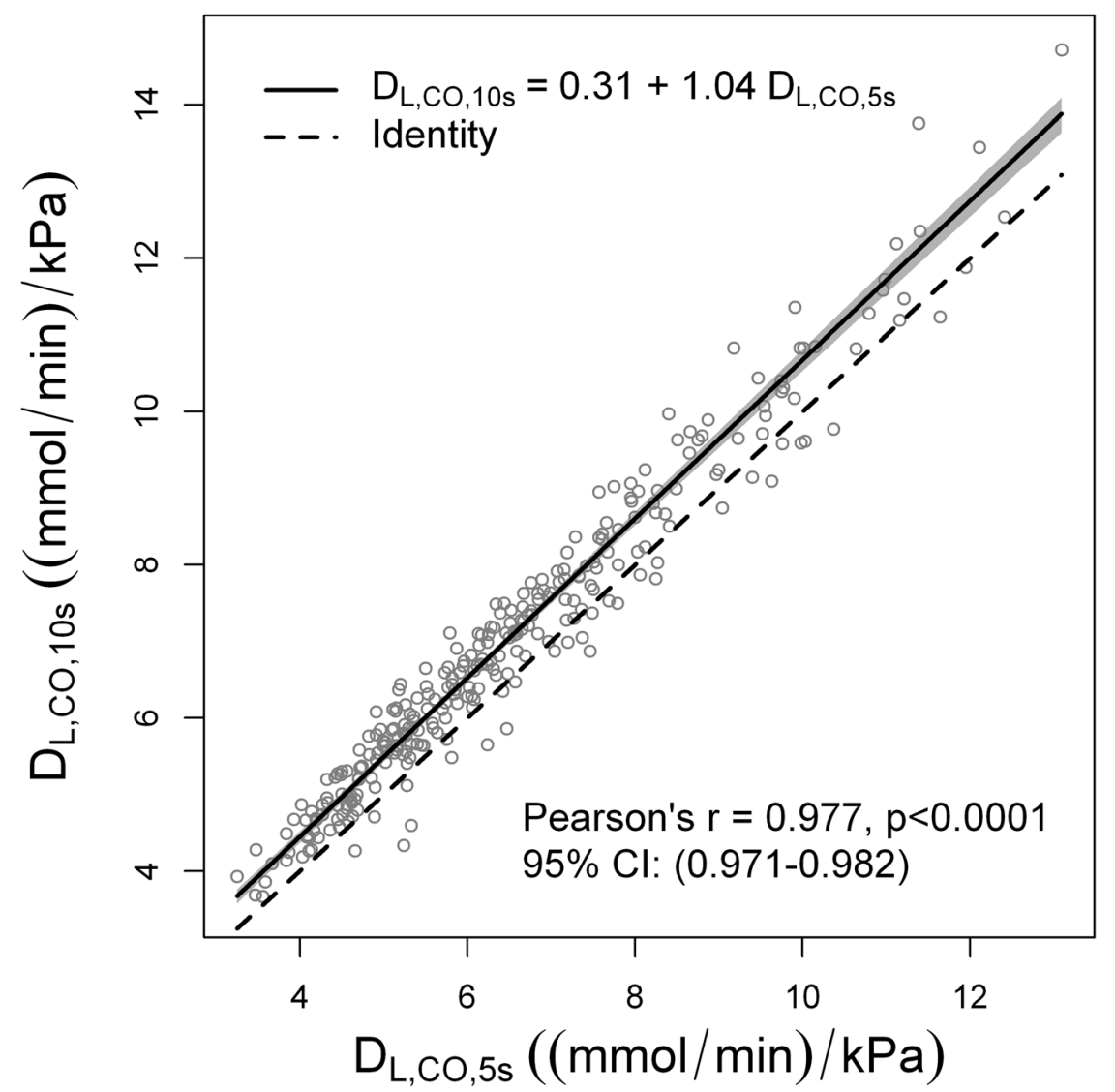

Figure 5. Comparison of $D_{L, C O, 5 s}$ and $D_{L, c o, 10 s}$. $D_{L, C O, 5 s}$ and $D_{L, c o, 10 s}$ were strongly correlated, with a Pearson's $r=0.977$. Passing Bablok regression showed that $D_{L, C O, 10 s}$ was systematically higher by a constant of 0.31 , and proportionally higher by a factor of 1.04 .

doi:10.1371/journal.pone.0113177.g005 


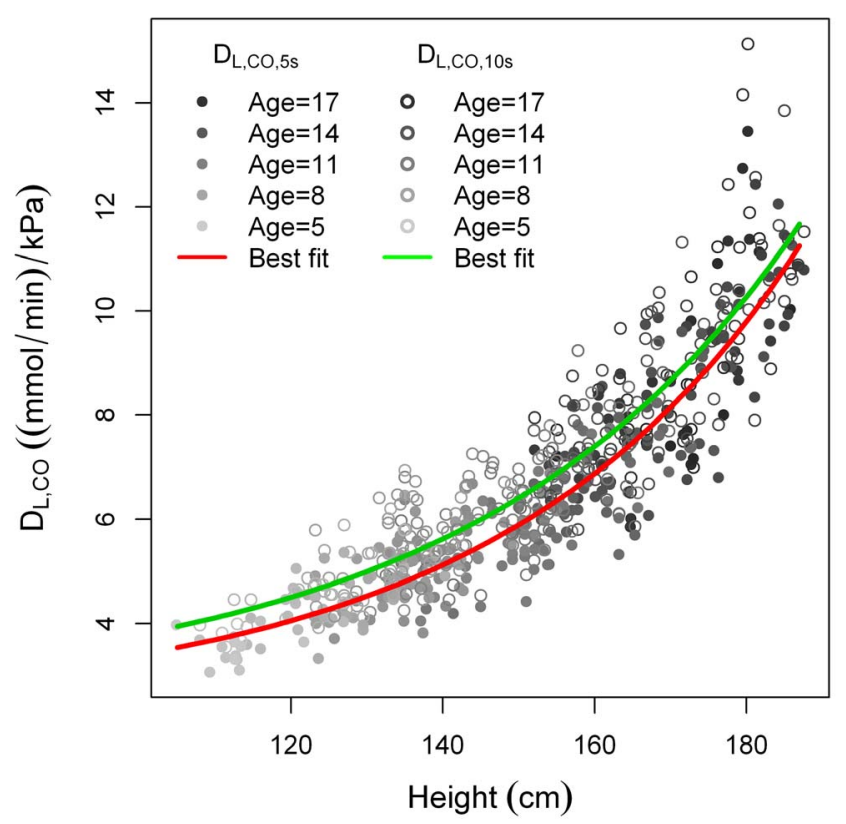

Figure 6. $D_{L, C O, 5 s}$ and $D_{L, C O, 10 s}$ plotted as a function of height.

doi:10.1371/journal.pone.0113177.g006

Vc and Dm

Vc and Dm both increase with height. (Figure 8 and 9 ).

\section{Discussion}

This is the first study to establish reference equations for the outcomes of

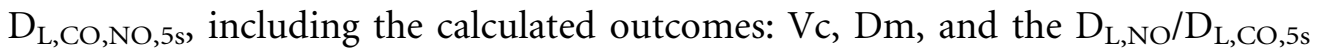
ratio, in a large group of healthy children of European descent. The measurement and evaluation of $\mathrm{Vc}$ and $\mathrm{Dm}$ can potentially provide valuable information about the causes of decreased diffusing capacity and the development and progression of lung disease or vascular disorders from the age of 5 years.

Vc and Dm are not entirely accepted as robust parameters, partially due to the lack of reference equations, which limits their clinical and scientific use. A more problematic issue is the current lack of agreement regarding the true value of $\Theta C O$ and the relationship with arterial oxygen pressure. The calculated $\mathrm{Vc}_{\mathrm{c}}$ is dependent on this value and will vary depending on which equation is used. The equation utilized in this paper was based on measurements performed at $\mathrm{pH} 7.4$ [24], for conventional reasons, and because it is closer to a physiological value. Finally, another topic of debate is $\alpha$, the ratio of NO to CO diffusivity. In the present study, a physical $\alpha$ value of 1.97 was used [4] , but an alternative empiric value of 2.42 has been proposed [4] , [32] .

The $\mathrm{D}_{\mathrm{L}, \mathrm{NO}} / \mathrm{D}_{\mathrm{L}, \mathrm{CO}, 5 \mathrm{~s}}$ ratio has been proposed as a measure of the relative properties of $\mathrm{Dm}$ and $\mathrm{Vc}[\underline{33}]$. Previous studies have concluded that the $\mathrm{D}_{\mathrm{L}, \mathrm{NO}} / \mathrm{D}_{\mathrm{L}, \mathrm{CO}, 5 \mathrm{~s}}$ ratio 


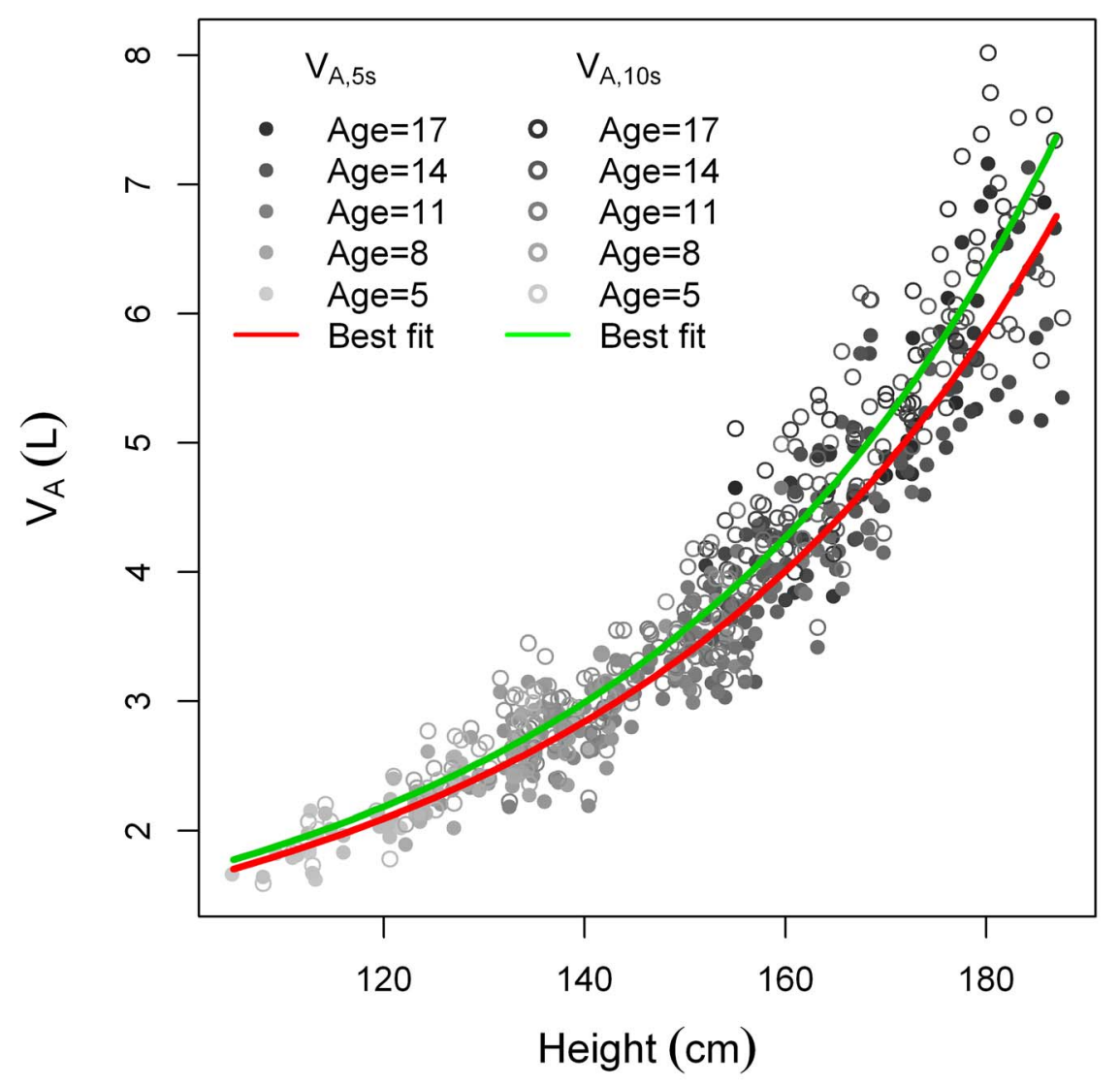

Figure 7. $\mathrm{Va}_{5 \mathrm{~s}}$ and $\mathrm{Va}_{10 \mathrm{~s}}$ plotted as a function of height.

doi:10.1371/journal.pone.0113177.g007

in adults is independent of age [12], [34]. Figure 3 is produced via a "best fit"model for the available data, and may not reflect the true bio-physical relationship between height and this ratio. That being said, we found that the ratio increased with height until mid pubertal age at approximately 14 years and then reached a plateau.

We have shown that both Vc and Dm increase with height(Figure 8 and 9 ). As stated in the introduction, according to current opinion the diffusing capacity of $\mathrm{NO}\left(\mathrm{D}_{\mathrm{L}, \mathrm{NO}}\right)$ reflects both $\mathrm{Dm}$ and $\Theta_{\mathrm{CO}} * \mathrm{Vc}$, whereas $\mathrm{D}_{\mathrm{L}, \mathrm{CO}}$ primarily reflects Vc. With increasing height $\mathrm{D}_{\mathrm{L}, \mathrm{NO}}$ will increase relatively more than $\mathrm{D}_{\mathrm{L}, \mathrm{CO}}$ leading to the $\mathrm{D}_{\mathrm{L}, \mathrm{NO}} / \mathrm{D}_{\mathrm{L}, \mathrm{CO}, 5 \mathrm{~s}}$ reaching a plateau around $140 \mathrm{~cm}$.

The lower $\mathrm{D}_{\mathrm{L}, \mathrm{NO}} / \mathrm{D}_{\mathrm{L}, \mathrm{CO}, 5 \mathrm{~s}}$ in younger and smaller children may be due to a greater rate of capillary growth compared to lung surface growth or to a relatively thicker membrane in the young. As height increases with age, a compensatory relatively larger increase in Dm would result in an increasing ratio. Alveolarization has been shown to continue through out childhood and adolescence [ $\underline{35}$ ] and could help explain the increase in Dm. The literature on this topic is scarce, and future studies are needed to understand and interpret the effect of age and height on the $\mathrm{D}_{\mathrm{L}, \mathrm{NO}} / \mathrm{D}_{\mathrm{L}, \mathrm{CO}, 5 \mathrm{~s}}$ ratio. 


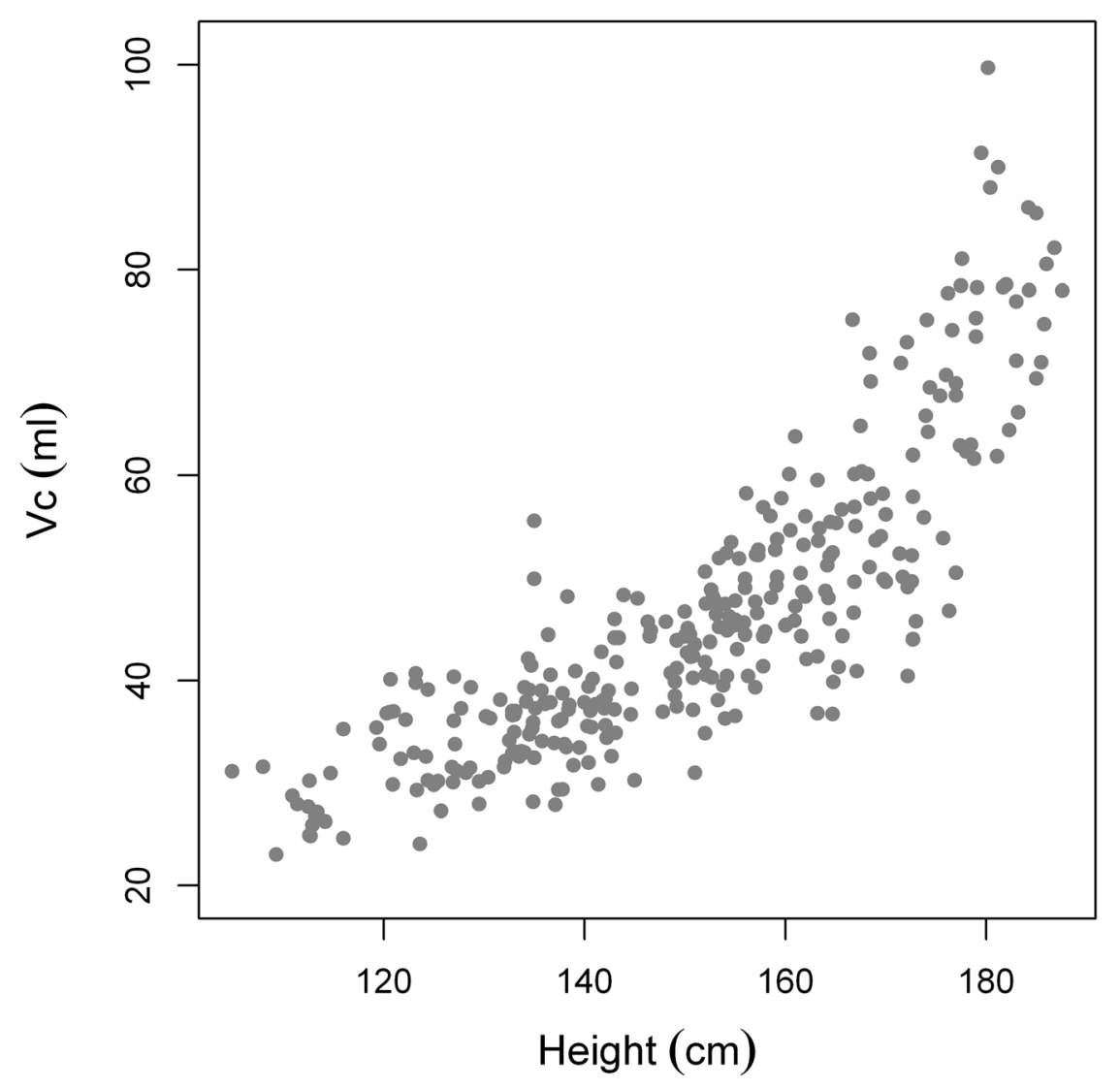

Figure 8. Vc plotted as a function of height.

doi:10.1371/journal.pone.0113177.g008

$\mathrm{D}_{\mathrm{L}, \mathrm{CO}, 10 \mathrm{~s}}$

The reference values calculated in the present study for $D_{L, C O, 10 s}$ were slightly higher than existing, published reference values. One possible reason for this difference is that the present study population included children with both parents of European descent, whereas Koopman et al. included children with only one parent of European descent [16]. Ethnic differences in $\mathrm{D}_{\mathrm{L}}$ in adults are small, but well established [36], [37]. Another reason for the difference is the pulmonary function equipment; the equipment used in the present study and by Koopman et al. were very similar, whereas the apparatus' used by Kim et al. [19] at their two locations were from two different manufacturers. Furthermore, even with the same apparatus, differences in software including various corrections, may lead to the observed differences.

Our results stress the importance of creating reference equations specific for a single population, or at least validating existing reference equations prior to implementing them in a laboratory setting. 


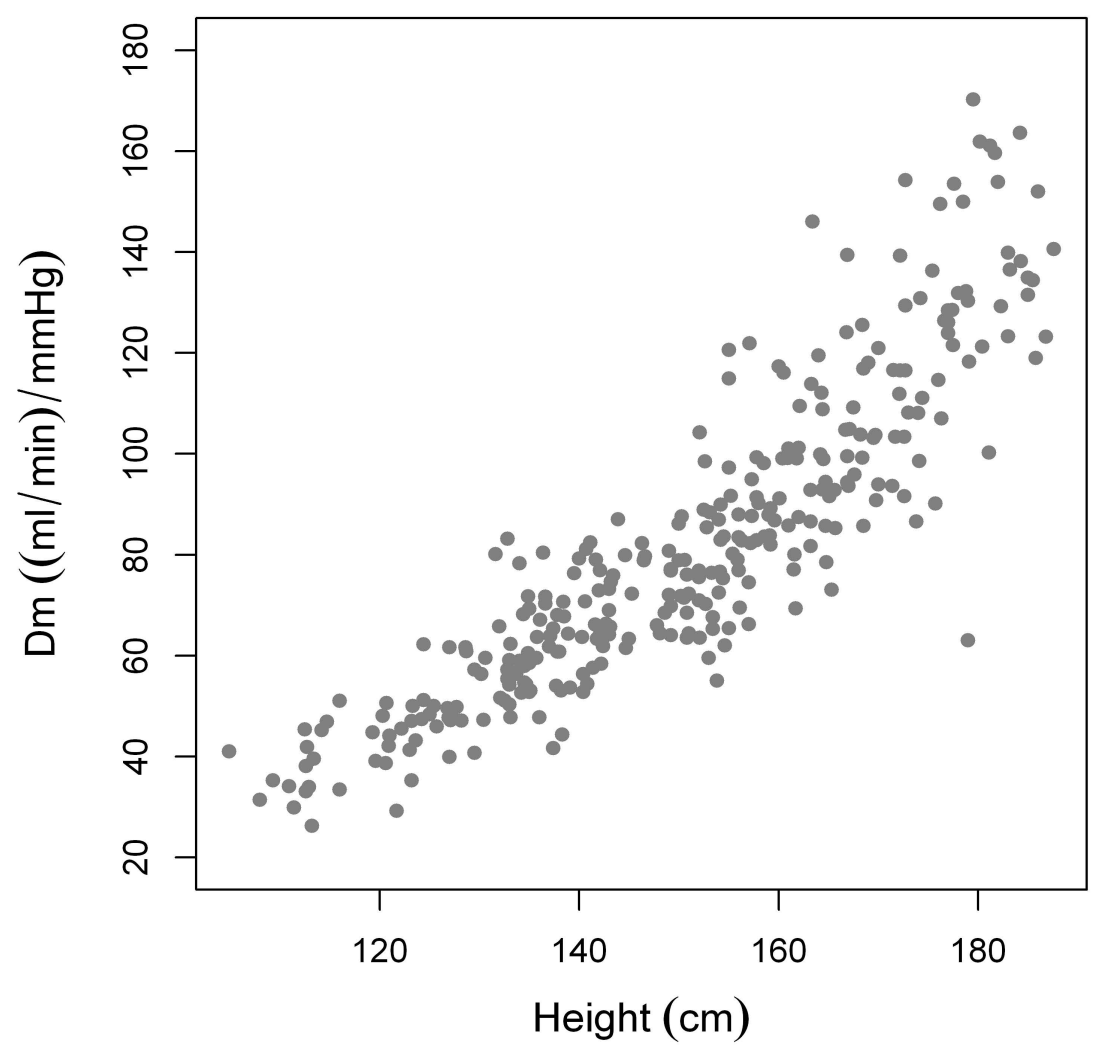

Figure 9. Dm plotted as a function of height.

doi:10.1371/journal.pone.0113177.g009

$D_{L, C O, 5 s}$ Vs. $D_{L, C O, 10 s}$

Although the primary purpose of measuring $\mathrm{D}_{\mathrm{L}, \mathrm{CO}, 10 \mathrm{~s}}$ was to secure a meaningful correlation to the much more scarcely described $D_{\mathrm{L}, \mathrm{CO}, \mathrm{NO}, 5 \mathrm{~s}}$ technique, we secondarily wished to compare $\mathrm{D}_{\mathrm{L}, \mathrm{CO}}$ measured by the two techniques. As expected we found a significant, systematic difference between $\mathrm{D}_{\mathrm{L}, \mathrm{CO}, 5 \mathrm{~s}}$ and $\mathrm{D}_{\mathrm{L}, \mathrm{CO}, 10 \mathrm{~s}}$. The difference in $\mathrm{D}_{\mathrm{L}, \mathrm{CO}}$ can be caused by a number of factors, as the two methods vary in a number of ways. See table 1. First, methane and helium may have different distributions in the lung owing to their respective physical properties; they have also different solubility in tissue. This may lead to a difference in $\mathrm{V}_{\mathrm{A}}$ and a resulting difference in $\mathrm{D}_{\mathrm{L}, \mathrm{CO}}$ as $\mathrm{D}_{\mathrm{LCO}}=\mathrm{K}_{\mathrm{CO}} * \mathrm{~V}_{\mathrm{A}}$. Second, the sample method varies, with a physical gas sample being collected in the case of

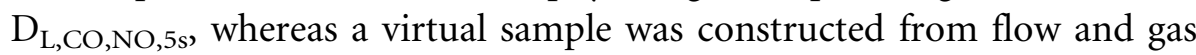
concentration signals in the case of $\mathrm{D}_{\mathrm{L}, \mathrm{CO}, 10 \mathrm{~s}}$. Finally, we speculate if the difference in the kinetics of $\mathrm{NO}$ and $\mathrm{CO}$ in binding with hemoglobin may play a roll.

Older studies on $\mathrm{D}_{\mathrm{L}, \mathrm{CO}, 10 \mathrm{~s}}$ focusing on varying breath-hold times, keeping all other factors constant, have shown that breath-hold time alone, influences $\mathrm{K}_{\mathrm{CO}}$, leading to a decreased $\mathrm{D}_{\mathrm{L}, \mathrm{CO}}$ with an increased breath-hold time [38]. This is in 
contrast to our findings, but apparently the mentioned differences in methodology other than breath-hold, have a greater impact on $\mathrm{D}_{\mathrm{L}, \mathrm{CO}}$.

In summary, the two methods vary in a number of ways and $\mathrm{D}_{\mathrm{L}, \mathrm{CO}}$ measured using $\mathrm{D}_{\mathrm{L}, \mathrm{CO}, \mathrm{NO}, 5 \mathrm{~s}}$ and $\mathrm{D}_{\mathrm{L}, \mathrm{CO}, 10 \mathrm{~s}}$ cannot be used interchangeably for monitoring pulmonary disease. More research is required to determine how the mentioned factors combine to influence $\mathrm{D}_{\mathrm{L}, \mathrm{CO}}$. A given value of $\mathrm{D}_{\mathrm{L}, \mathrm{CO}}$ can only be evaluated using reference equations produced with the same methodology and breath-hold time as recently confirmed [39].

\section{$\mathrm{CO}$ and NO backpressure}

The participants performed two or three tests, and rarely up to six repetitions of both $\mathrm{D}_{\mathrm{L}, \mathrm{CO}, \mathrm{NO}, 5 \mathrm{~s}}$ and $\mathrm{D}_{\mathrm{L}, \mathrm{CO}, 10 \mathrm{~s}}$, resulting in a maximum of 12 tests in a single sitting. Repeating measurements of $\mathrm{D}_{\mathrm{L}, \mathrm{CO}, 10 \mathrm{~s}}$ leads to an accumulation of $\mathrm{CO}$ in the blood, creating $\mathrm{CO}$ backpressure and decreasing $\mathrm{D}_{\mathrm{L}, \mathrm{CO}}$. However, recent work by Zavorsky showed that up to 12 tests can be performed in adults without significantly lowering the $\mathrm{D}_{\mathrm{L}, \mathrm{CO}}$. Furthermore, in regards to $\mathrm{D}_{\mathrm{L}, \mathrm{CO}, \mathrm{NO}, 5 \mathrm{~s}}$, up to 22 repetitions does not lead to a decrease in $\mathrm{D}_{\mathrm{L}, \mathrm{NO}}[\underline{40}$ ]. Taking this into account, we have no reason to suspect $\mathrm{CO}$ or $\mathrm{NO}$ backpressure to be of influence in the present study.

\section{Quality control}

Measuring lung function in this age group requires extra time and effort, but it is feasible. Most of the young children were able to perform the measurements according to ATS/ERS guidelines, but some had greater variability between measurements than normally accepted. This difference was partially due to the limited attention span of the children, who were not always able to perform repeated tests if the first two measurements did not comply with the ATS/ERS standard of a maximum $10 \%$ difference between measurements. We included measurements with greater variability, as they did not affect the estimated reference equations. Accepting greater variation in children makes sense if the alternative is to discard measurements completely.

The ATS/ERS guidelines recommend an acceptance criterion of $\mathrm{V}_{\mathrm{IN}} / \mathrm{VC} \geq 85 \%$ for adults. The recommendation is based on $\mathrm{D}_{\mathrm{LCO} 10 \mathrm{~s}}$ measured in a large group of adults, where $72 \%, 86 \%$, and $92 \%$ of the participants were able to achieve a $\mathrm{V}_{\text {IN }} /$ VC ratio of $90 \%, 85 \%$, and $80 \%$, respectively. Therefore, the recommended ratio, i.e., $85 \%$, is a relatively arbitrary value and the guidelines state that $\mathrm{V}_{\mathrm{IN}} / \mathrm{VC}<85 \%$ may still have clinical utility [2].

Although most of our participants were able to inhale to more than $85 \%$ of FVC, some were not, despite multiple attempts and prompting and otherwise performing an adequate maneuver.

We found no differences between reference equations including measurements with $\mathrm{V}_{\text {IN }} / \mathrm{FVC}>80 \%$ and reference equations only including $\mathrm{V}_{\text {IN }} / \mathrm{FVC}>85 \%$. 
In summary, we accepted measurements that did not meet ATS/ERS quality criteria because these measurements had no effect on the resulting equations. In the future, specific pediatric guidelines for both $\mathrm{D}_{\mathrm{L}, \mathrm{CO}, \mathrm{NO}, 5 \mathrm{~s}}$ and $\mathrm{D}_{\mathrm{L}, \mathrm{CO}, 10 \mathrm{~s}}$ would be relevant.

\section{Strengths and limitations}

The primary strength of this study is the large and acceptable age distribution of healthy children and adolescents from varying demographic backgrounds. Furthermore, this study was completed in two laboratory setups with identical equipment, as described in the online supplement. The same two technicians performed all measurements, resulting in a high level of repeatability and a systematic approach. In addition, we included children as young as 5 years of age, expanding our ability to adequately evaluate advanced pulmonary function in this age group. Finally, our calculated reference equations for $\mathrm{D}_{\mathrm{L}, \mathrm{CO}, 10 \mathrm{~s}}$ corresponded well to recently published equations, in particular those of Koopmans et al. [16]

In hindsight, it would have been beneficial to include a "young adult" group, 18-22 years old, in this study, as it would open up the possibility of bridging reference equations to include children, adolescents, young adults, and adults.

For the youngest children with a $\mathrm{VC}<1.5$ liters, we reduced the discard volume to $500 \mathrm{ml}$. If the $\mathrm{VC}$ is even lower, as in the case of disease, this method may not be suitable. Multiple other techniques exist for $\mathrm{D}_{\mathrm{L}, \mathrm{CO}}$. These include the steady state method, particularly suitable for infants or anaesthetized patients, or the rebreathing and intrabreath method, that both require cooperation, but can be performed in patients with lower lung volumes [41]. So far these modifications have not been applied to $\mathrm{D}_{\mathrm{L}, \mathrm{CO}, \mathrm{NO}}$.

\section{Conclusion}

This study is the first to create pediatric reference equations for the outcomes $\mathrm{D}_{\mathrm{L}, \mathrm{CO}, 5 \mathrm{~s}}, \mathrm{D}_{\mathrm{L}, \mathrm{NO}}$, and the calculated outcomes $\mathrm{D}_{\mathrm{L}, \mathrm{NO}} / \mathrm{D}_{\mathrm{L}, \mathrm{CO}, 5 \mathrm{~s}}, \mathrm{Vc}$, and $\mathrm{Dm}$ measured by $\mathrm{D}_{\mathrm{L}, \mathrm{CO}, \mathrm{NO}, 5 \mathrm{~s}}$ in healthy children and adults, of European descent. These equations are based on a large population with a broad age range, including children as young as 5 years of age. We expect that the present reference equations can be applied to similar populations throughout Europe, Australia and North America.

We hope that having reliable reference equations for $\mathrm{Dm}, \mathrm{Vc}$, and $\mathrm{D}_{\mathrm{L}, \mathrm{NO}} /$ $\mathrm{D}_{\mathrm{L}, \mathrm{CO}, 5 \mathrm{~s}}$ will lead to improved diagnostic evaluation and provide a monitoring tool for the treatment of children presenting with diffuse interstitial lung disease, whether it is a pure alveolocapillary membrane disturbance or pulmonary micro vascular disease. In particular, we believe that the $\mathrm{D}_{\mathrm{L}, \mathrm{NO}} / \mathrm{D}_{\mathrm{L}, \mathrm{CO}, 5 \mathrm{~s}}$ ratio has great potential, as it is independent of the assumptions and models used to calculate Vc and $\mathrm{Dm}$, that may be easily questionable. However, the clinical utility of Vc, Dm, and $\mathrm{D}_{\mathrm{L}, \mathrm{NO}} / \mathrm{D}_{\mathrm{L}, \mathrm{CO}, 5 \mathrm{~s}}$ still needs to be evaluated in future studies. We acknowledge that multicenter studies are required for external validation of these results. We 
invite researchers to compare their results, in children with well known pathological features of the lung, with the results of this study. This will achieve increased understanding of the physiological meaning of the described measurements and their application in the early detection and monitoring of diseases.

\section{Supporting Information}

Figure S1. Age and gender distribution of participants.

doi:10.1371/journal.pone.0113177.s001 (TIFF)

Figure S2. Quality control. Participants with more than 10\% difference between two independent measurements of $\mathrm{D}_{\mathrm{L}, \mathrm{CO}, 5 \mathrm{~s}}$ were evaluated, as this is in contrast to ATS/ERS guidelines.

doi:10.1371/journal.pone.0113177.s002 (TIFF)

Figure S3. Quality control. Participants with more than $10 \%$ difference between two independent measurements of inspiratory volume $\left(\mathrm{V}_{\mathrm{IN}, 5 \mathrm{~s}}\right)$ were evaluated, as this is in contrast to ATS/ERS guidelines.

doi:10.1371/journal.pone.0113177.s003 (TIFF)

Figure S4. Quality control. Participants with more than $10 \%$ difference between two independent measurements of $\mathrm{D}_{\mathrm{L}, \mathrm{CO}, 10 \text { s }}$ were evaluated, as this is in contrast to ATS/ERS guidelines.

doi:10.1371/journal.pone.0113177.s004 (TIFF)

Figure S5. Quality control. Participants with more than 10\% difference between two independent measurements of inspiratory volume $\mathrm{V}_{\mathrm{IN}, 10 \mathrm{~s}}$ were evaluated, as this is in contrast to ATS/ERS guidelines.

doi:10.1371/journal.pone.0113177.s005 (TIFF)

Figure S6. Quality control. Measurements of $\mathrm{V}_{\mathrm{IN}, 5 \mathrm{~s}} / \mathrm{FVC}$ between $80 \%$ and $85 \%$ were evaluated as ATS/ERS requires values $>85 \%$.

doi:10.1371/journal.pone.0113177.s006 (TIFF)

Figure S7. Quality control. Measurements of $\mathrm{V}_{\mathrm{IN}, 10 \mathrm{~s}} / \mathrm{FVC}$ between $80 \%$ and $85 \%$ were evaluated as ATS/ERS requires values $>85 \%$.

doi:10.1371/journal.pone.0113177.s007 (TIFF)

Appendix S1. Age distribution.

doi:10.1371/journal.pone.0113177.s008 (DOCX)

Appendix S2. Excel worksheet.

doi:10.1371/journal.pone.0113177.s009 (XLSX)

\section{Acknowledgments}

This study would not have been possible without the cooperation and goodwill of The Danish Pediatric Pulmonary Service, as well as the staff and parents at Ingrid Jespersens School. 


\section{Author Contributions}

Conceived and designed the experiments: AT BH KN JM. Performed the experiments: BH AT. Analyzed the data: AT BH KN JLM JM FB. Wrote the paper: AT BH KN FB JLM JM.

\section{References}

1. Krogh M (1915) The diffusion of gases through the lungs of man. The Journal of physiology 49: $271-$ 300.

2. Macintyre N, Crapo RO, Viegi G, Johnson DC, van der Grinten CP, et al. (2005) Standardisation of the single-breath determination of carbon monoxide uptake in the lung. The European respiratory journal: official journal of the European Society for Clinical Respiratory Physiology 26: 720-735.

3. Roughton FJ, Forster RE (1957) Relative importance of diffusion and chemical reaction rates in determining rate of exchange of gases in the human lung, with special reference to true diffusing capacity of pulmonary membrane and volume of blood in the lung capillaries. Journal of applied physiology 11: 290-302.

4. Guénard H, Varène N, Vaida $\mathbf{P}$ (1987) Determination of lung capillary blood volume and membrane diffusing capacity in man by the measurements of NO and CO transfer. Respiration physiology 70: 113120.

5. Borland CD, Higenbottam TW (1989) A simultaneous single breath measurement of pulmonary diffusing capacity with nitric oxide and carbon monoxide. The European respiratory journal: official journal of the European Society for Clinical Respiratory Physiology 2: 56-63.

6. Borland CD, Dunningham H, Bottrill F, Vuylsteke A, Yilmaz C, et al. (2010) Significant blood resistance to nitric oxide transfer in the lung. Journal of applied physiology 108: 1052-1060.

7. Hughes JM (2013) Invited editorial on "Lung membrane conductance and capillary volume derived from the NO and CO transfer in high altitude newcomers". J Appl Physiol (1985) 115: 153-154.

8. Dressel H, Filser L, Fischer R, Marten K, Muller-Lisse U, et al. (2009) Lung diffusing capacity for nitric oxide and carbon monoxide in relation to morphological changes as assessed by computed tomography in patients with cystic fibrosis. BMC pulmonary medicine 9: 30.

9. van der Lee I, Gietema HA, Zanen P, van Klaveren RJ, Prokop M, et al. (2009) Nitric oxide diffusing capacity versus spirometry in the early diagnosis of emphysema in smokers. Respiratory medicine 103: 1892-1897.

10. van der Lee I, Zanen P, Grutters JC, Snijder RJ, van den Bosch JM (2006) Diffusing capacity for nitric oxide and carbon monoxide in patients with diffuse parenchymal lung disease and pulmonary arterial hypertension. Chest 129: 378-383.

11. Borland C, Cox Y, Higenbottam T (1996) Reduction of pulmonary capillary blood volume in patients with severe unexplained pulmonary hypertension. Thorax 51: 855-856.

12. Hughes JM, van der Lee I (2013) The TL,NO/TL,CO ratio in pulmonary function test interpretation. The European respiratory journal: official journal of the European Society for Clinical Respiratory Physiology 41: 453-461.

13. Rouatbi S, Ouahchi YF, Ben Salah C, Ben Saad H, Harrabi I, et al. (2006) [Physiological factors influencing pulmonary capillary volume and membrane diffusion]. Revue des maladies respiratoires 23 : 211-218.

14. Rouatbi S, Khemis M, Garrouch A, Ben Saad H (2014) Reference values of capillary blood volume and pulmonary membrane diffusing capacity in North African boys aged 8 to 16 years. Egyptian Journal of Chest Diseases and Tuberculosis 63: 705-715.

15. Kim YJ, Hall GL, Christoph K, Tabbey R, Yu Z, et al. (2011) Pulmonary diffusing capacity in healthy caucasian children. Pediatric pulmonology: 469-475.

16. Koopman M, Zanen P, Kruitwagen CL, van der Ent CK, Arets HG (2011) Reference values for paediatric pulmonary function testing: The Utrecht dataset. Respiratory medicine 105: 15-23. 
17. Thomas A, Hanel B, Buchvald F, Marott LJ, Mortensen J, et al. (2013) The Single Breath Diffusing Capacity Of The Lung In Healthy Danish Children 5 To 17 Years Old: Reference Values For The Single Breath Diffusing Capacity Using Carbon Monoxide And Nitric Oxide. American Thoracic Society.

18. Quanjer PH, Stanojevic S, Cole TJ, Baur X, Hall GL, et al. (2012) Multi-ethnic reference values for spirometry for the 3-95 year age range: the global lung function 2012 equations. The European respiratory journal: official journal of the European Society for Clinical Respiratory Physiology: 13241343.

19. Kim YJ, Hall GL, Christoph K, Tabbey R, Yu Z, et al. (2011) Pulmonary diffusing capacity in healthy caucasian children. Pediatric pulmonology.

20. Jones RS, Meade F (1961) A theoretical and experimental analysis of anomalies in the estimation of pulmonary diffusing capacity by the single breath method. Quarterly journal of experimental physiology and cognate medical sciences 46: 131-143.

21. Cotes JE, Leathart GL (1993) Lung function: assessment and application in medicine. Oxford; Boston: Blackwell Scientific Publications. xi, 768 p. p.

22. von Westernhagen F, Smidt U (1978) The significance of the difference between slow inspiratory and forced expiratory vital capacity. Lung 154: 289-297.

23. Zavorsky GS, Wilson B, Harris JK, Kim DJ, Carli F, et al. (2010) Pulmonary diffusion and aerobic capacity: is there a relation? Does obesity matter? Acta physiologica 198: 499-507.

24. Forster RE (1987) Diffusion of Gases Across the Alveolar Membrane. In: Farhi LE TS, editor. Handbook of Physiology, section 3: The Respiratory System: American Physiological Society, Washington, DC. pp. 71-88.

25. Martinot JB, Mule M, de Bisschop C, Overbeek MJ, Le-Dong NN, et al. (2013) Lung membrane conductance and capillary volume derived from the $\mathrm{NO}$ and $\mathrm{CO}$ transfer in high-altitude newcomers. J Appl Physiol (1985) 115: 157-166.

26. van Buuren S, Fredriks $\mathbf{M}$ (2001) Worm plot: a simple diagnostic device for modelling growth reference curves. Stat Med 20: 1259-1277.

27. Royston P, Wright EM (2000) Goodness-of-fit statistics for age-specific reference intervals. Stat Med 19: 2943-2962.

28. Cook RD, Weisberg S (1982) Residuals and influence in regression. New York: Chapman and Hall. 229 p.

29. Belsley DA, Kuh E, Welsch RE (1980) Regression diagnostics: identifying influential data and sources of collinearity. New York: Wiley. $102 \mathrm{p}$.

30. Williams D (1987) Generalized linear model diagnostics using the deviance and single case deletions. Applied Statistics: 181-191.

31. Fox J (1997) Applied regression analysis, linear models, and related methods: Sage Publications, Incorporated.

32. Phansalkar AR, Hanson CM, Shakir AR, Johnson RL, Jr., Hsia CC (2004) Nitric oxide diffusing capacity and alveolar microvascular recruitment in sarcoidosis. American journal of respiratory and critical care medicine 169: 1034-1040

33. Glenet SN, De Bisschop C, Vargas F, Guénard HJ (2007) Deciphering the nitric oxide to carbon monoxide lung transfer ratio: physiological implications. The Journal of physiology 582: 767-775.

34. Aguilaniu B, Maitre J, Glenet S, Gegout-Petit A, Guénard H (2008) European reference equations for $\mathrm{CO}$ and NO lung transfer. The European respiratory journal: official journal of the European Society for Clinical Respiratory Physiology 31: 1091-1097.

35. Narayanan M, Owers-Bradley J, Beardsmore CS, Mada M, Ball I, et al. (2012) Alveolarization continues during childhood and adolescence: new evidence from helium-3 magnetic resonance. American journal of respiratory and critical care medicine 185: 186-191.

36. Neas LM, Schwartz J (1996) The determinants of pulmonary diffusing capacity in a national sample of U.S. adults. American journal of respiratory and critical care medicine 153: 656-664.

37. Cotes JE, Chinn DJ, Quanjer PH, Roca J, Yernault JC (1993) Standardization of the measurement of transfer factor (diffusing capacity). Report Working Party Standardization of Lung Function Tests, 
European Community for Steel and Coal. Official Statement of the European Respiratory Society. The European respiratory journal Supplement 16: 41-52.

38. Blakemore WS, Forster RE, Morton JW, Ogilvie CM (1957) A standardized breath holding technique for the clinical measurement of the diffusing capacity of the lung for carbon monoxide. The Journal of clinical investigation 36: 1-17.

39. Dressel H, Filser L, Fischer R, de la Motte D, Steinhaeusser W, et al. (2008) Lung diffusing capacity for nitric oxide and carbon monoxide: dependence on breath-hold time. Chest 133: 1149-1154.

40. Zavorsky GS (2013) The rise in carboxyhemoglobin from repeated pulmonary diffusing capacity tests. Respiratory physiology \& neurobiology 186: 103-108.

41. Cotes JE, Chinn DJ, Miller MR (2006) Lung function: physiology, measurement and application in medicine. Malden, Mass.; Oxford: Blackwell Pub. xi,, 636 pp. 